\title{
Differential mechanisms underlying responses of soil bacterial and fungal communities to nitrogen and phosphorus inputs in a subtropical forest
} \author{
Xiaoming Kang ${ }^{\text {Corresp., } 1}$, Bing Song ${ }^{\text {Corresp. } 4}$ \\ ${ }^{1}$ Institute of Wetland Research, Chinese Academy of Forestry, Beijing, China \\ 2 Institute of Geographic Sciences and Natural Resources Research, Beijing, China \\ 3 Jigongshan Natural Reserve, Xinyang, China \\ ${ }^{4}$ School of Resources and Environmental Engineering, Ludong University, Yantai, China \\ Corresponding Authors: Xiaoming Kang, Bing Song \\ Email address: xmkang@ucas.ac.cn, songbing@ldu.edu.cn
}

Yong $\mathrm{Li}^{1}$, Dashuan Tian ${ }^{2}$, Jinsong Wang ${ }^{2}$, Shuli Niu ${ }^{2}$, Jing Tian ${ }^{2}$, Denglong Ha ${ }^{3}$, Yuxi Qu ${ }^{3}$, Guangwei Jing ${ }^{3}$,

Atmospheric nitrogen $(\mathrm{N})$ deposition and phosphorus $(\mathrm{P})$ addition both can change soil bacterial and fungal community structure with a consequent impact on ecosystem functions. However, which factor plays an important role in regulating responses of bacterial and fungal community to $\mathrm{N}$ and $\mathrm{P}$ enrichments remains unclear. We conducted a manipulative experiment to simulate $\mathrm{N}$ and $\mathrm{P}$ inputs $\left(10 \mathrm{~g} \mathrm{~N} \cdot \mathrm{m}^{-2} \cdot \mathrm{yr}^{-1} \mathrm{NH}_{4} \mathrm{NO}_{3}\right.$ or $10 \mathrm{~g}$ $\mathrm{P} \cdot \mathrm{m}^{-2} \cdot \mathrm{yr}^{-1} \mathrm{NaH}_{2} \mathrm{PO}_{4}$ ) and compared their effects on soil bacterial and fungal species richness and community composition. The results showed that the addition of $\mathrm{N}$ significantly increased $\mathrm{NH}_{4}^{+}$and $\mathrm{Al}^{3+}$ by $99.6 \%$ and $57.4 \%$, respectively, and consequently led to a decline in soil pH from 4.18 to 3.75 after a five-year treatment. P addition increased $\mathrm{Al}^{3+}$ and available $\mathrm{P}$ by $27.0 \%$ and 10 -fold, respectively, but had no effect on soil $\mathrm{pH}$. $\mathrm{N}$ addition significantly decreased bacterial species richness and Shannon index and resulted in a substantial shift of bacterial community composition, whereas $\mathrm{P}$ addition did not. Neither $\mathrm{N}$ nor $\mathrm{P}$ addition changed fungal species richness, Shannon index, and fungal community composition. A structural equation model showed that the shift in bacterial community composition was related to an increase in soil acid cations. The principal component scores of soil nutrients showed a significantly positive relationship with fungal community composition. Our results suggest that $\mathrm{N}$ and $\mathrm{P}$ additions affect soil bacterial and fungal communities in different ways in subtropical forest. These findings highlight how the diversity of microbial communities of subtropical forest soil will depend on future scenarios of anthropogenic $\mathrm{N}$ deposition and $\mathrm{P}$ enrichment, with a particular sensitivity of bacterial community to $\mathrm{N}$ addition. 
1 Differential mechanisms underlying responses of soil bacterial and fungal communities to

2 nitrogen and phosphorus inputs in a subtropical forest

3 Yong $\mathrm{Li}^{1}$, Dashuan Tian ${ }^{2}$, Jinsong Wang ${ }^{2}$, Shuli $\mathrm{Niu}^{2}$, Jing Tian ${ }^{2}$, Denglong $\mathrm{Ha}^{3}$, Yuxi $\mathrm{Qu}^{3}$,

4 Guangwei Jing ${ }^{3}$, Xiaoming Kang ${ }^{1, *}$, Bing Song ${ }^{4, *}$

5

61 Beijing Key Laboratory of Wetland Services and Restoration, Institute of Wetland Research,

$7 \quad$ Chinese Academy of Forestry, Beijing 100091, China

$8{ }^{2}$ Key Laboratory of Ecosystem Network Observation and Modeling, Institute of Geographic

9 Sciences and Natural Resources Research, Chinese Academy of Sciences, Beijing 100101,

10 China

113 Jigongshan Natural Reserve, Xinyang 464000, China

124 School of Resources and Environmental Engineering, Ludong University, Yantai 264025,

13 China

14

$15 *$ Corresponding author:

16 Xiaoming Kang, Tel.: +86 106282 4153, Email: xmkang@ucas.ac.cn;

17 Bing Song, Tel.: +86 535668 1043, Email: songbing@ldu.edu.cn 


\section{Abstract}

21 Atmospheric nitrogen $(\mathrm{N})$ deposition and phosphorus $(\mathrm{P})$ addition both can change soil bacterial

22

and fungal community structure with a consequent impact on ecosystem functions. However, which factor plays an important role in regulating responses of bacterial and fungal community to $\mathrm{N}$ and $\mathrm{P}$ enrichments remains unclear. We conducted a manipulative experiment to simulate $\mathrm{N}$ and $\mathrm{P}$ inputs $\left(10 \mathrm{~g} \mathrm{~N} \cdot \mathrm{m}^{-2} \cdot \mathrm{yr}^{-1} \mathrm{NH}_{4} \mathrm{NO}_{3}\right.$ or $\left.10 \mathrm{~g} \mathrm{P} \cdot \mathrm{m}^{-2} \cdot \mathrm{yr}^{-1} \mathrm{NaH}_{2} \mathrm{PO}_{4}\right)$ and compared their effects on soil bacterial and fungal species richness and community composition. The results showed that the addition of $\mathrm{N}$ significantly increased $\mathrm{NH}_{4}{ }^{+}$and $\mathrm{Al}^{3+}$ by $99.6 \%$ and $57.4 \%$, respectively, and consequently led to a decline in soil $\mathrm{pH}$ from 4.18 to 3.75 after a five-year treatment. $\mathrm{P}$ addition increased $\mathrm{Al}^{3+}$ and available $\mathrm{P}$ by $27.0 \%$ and 10 -fold, respectively, but had no effect on soil $\mathrm{pH}$. $\mathrm{N}$ addition significantly decreased bacterial species richness and Shannon index and resulted in a substantial shift of bacterial community composition, whereas $\mathrm{P}$ addition did not. Neither N nor P addition changed fungal species richness, Shannon index, and fungal community composition. A structural equation model showed that the shift in bacterial community composition was related to an increase in soil acid cations. The principal component scores of soil nutrients showed a significantly positive relationship with fungal community composition. Our results suggest that $\mathrm{N}$ and $\mathrm{P}$ additions affect soil bacterial and fungal communities in different ways in subtropical forest. These findings highlight how the diversity of microbial communities of subtropical forest soil will depend on future scenarios of anthropogenic $\mathrm{N}$ deposition and $\mathrm{P}$ enrichment, with a particular sensitivity of bacterial community to $\mathrm{N}$ addition. 
41 Keywords: Nitrogen deposition, phosphorus addition, microbial diversity, community

42 composition, amplicon sequencing, subtropical forest, soil bacteria and fungi 


\section{Introduction}

46 Nitrogen $(\mathrm{N})$ and phosphorus $(\mathrm{P})$ inputs to the ecosystem have greatly increased due to

47 anthropogenic activities, mainly originating from fossil fuel combustion, agricultural

48 fertilization, and dust or ash production (Galloway et al. 2008; Stevens 2019; Wang et al. 2014).

49 Excessive $\mathrm{N}$ and $\mathrm{P}$ inputs could result in many adverse impacts, including soil acidification (Guo

50 et al. 2010; Mao et al. 2017; Tian \& Niu 2015) and nutrient imbalance (Peñuelas et al. 2013),

51 although $\mathrm{N}$ and $\mathrm{P}$ have been considered as limiting factors for plant growth (Harpole et al. 2011).

52 Moreover, elevated $\mathrm{N}$ availability may aggravate P limitation of ecosystem productivity (Li et al.

53 2016). A large body of research focusing on aboveground plant community responses have

54 demonstrated multiple effects with nutrient additions, including biodiversity loss (Hooper et al.

55 2012), species composition, and associated ecosystem services, such as terrestrial carbon

56 dynamics (Isbell et al. 2013; LeBauer \& Treseder 2008). However, the responses of

57 belowground microorganisms to nutrient additions, including general taxonomic traits and

58 related function shifts, remain unclear (Leff et al. 2015; Ma et al. 2019; Ma et al. 2016; Wei et al.

59 2018). In particular, integrated field experimental investigations of both bacterial and fungal

60 responses to $\mathrm{N}$ and $\mathrm{P}$ additions are needed to improve our understanding of how the soil

61 microbial community structure shifts in response to nutrient addition and whether the bacterial

62 and fungal responses are consistent.

63 Soil microbial communities are sensitive to N enrichment (Dai et al. 2018; Ramirez et al.

64 2012; Treseder 2008). On average and based on a global meta-analysis, across all of the studies 
65

66

67

68

69

70

71

72

73

74

75

76

77

78

79

80

81

82

83

84

in agro-ecosystems, the abundances of Proteobacteria and Actinobacteria significantly increased

by $2.2 \%$ and $1.1 \%$, respectively, and the abundance of Acidobactria decreased by $2.3 \%$ under N addition, which suggest differential sensitivity of bacterial phyla to $\mathrm{N}$ inputs (Dai et al. 2018). $\mathrm{N}$ addition could lead to elevated $\mathrm{N}$ availability (Chen et al. 2019), ammonium toxicity (Van Den Berg et al. 2005), acid cation toxicity (Chen et al. 2016; Tian \& Niu 2015), and loss of base mineral cations (Bowman et al. 2008). Meanwhile, several potential driving factors were proposed to account for shifts in sensitive microbial communities in some ecosystems (Nie et al. 2018). First, soil $\mathrm{pH}$ has been reported as a strong predictor of soil bacterial community composition at the continental scale (Lauber et al. 2009; Rousk et al. 2010). A significantly positive correlation between diversity of bacteria and soil $\mathrm{pH}$ might be attributable to narrow $\mathrm{pH}$ ranges for optimal growth of bacteria (Rousk et al. 2010). However, fungal community composition is less affected by soil $\mathrm{pH}$ because fungi generally exhibit wider $\mathrm{pH}$ ranges for optimal growth (Rousk et al. 2010). Second, N addition could directly affect soil bacterial community composition through modified ammonium $\mathrm{N}$ concentration (Nie et al. 2018; Zeng et al. 2016; Zhou et al. 2017). Soil bacterial community composition is closely related to soil $\mathrm{NH}_{4}^{+}{ }_{-}$ $\mathrm{N}$ content in tropical forest soil under $\mathrm{N}$ enrichment due to a narrow $\mathrm{pH}$ decrease in severely acidic soil ( $\mathrm{pH}<4.5)($ Nie et al. 2018). Finally, a positive relationship between plant and fungal beta diversity has been reported under $\mathrm{N}$ enrichment, soil properties including soil inorganic $\mathrm{N}$, $\mathrm{pH}$, and associated extractable cations being correlated with compositional changes in plant and fungal communities (Chen et al. 2018b). Although those mechanisms have previously been 
85

investigated, comprehensive studies on different regulatory pathways of $\mathrm{N}$ addition on bacterial and fungal community structure in forest ecosystems are limited.

$\mathrm{P}$ availability plays an important role in affecting microbial growth; however, our understanding of soil microbial community responses to elevated P inputs remains limited (Leff et al. 2015; Ma et al. 2019; Ma et al. 2016). Moreover, the effects of P input on bacterial and fungal community composition can differ (Cassman et al. 2016; Jorquera et al. 2014; Liu et al. 2013; Liu et al. 2012b). Previous studies have demonstrated that $\mathrm{P}$ enrichment induces shifts in microbial community composition by increasing $\mathrm{P}$ availability and altering soil and plant chemistry (DeForest \& Scott 2010; Lagos et al. 2016; Leff et al. 2015; Liu et al. 2012a; Liu et al. 2013; Teng et al. 2018). Other studies have reported that only $\mathrm{N}$ enrichment influences bacterial abundance and community composition, whereas $\mathrm{P}$ input did not because soil $\mathrm{pH}$ decreases only with $\mathrm{N}$ addition (Jorquera et al. 2014; Wang et al. 2018) or because bacterial community was limited by other resources (Ma et al. 2019). The abovementioned pathways have largely been studied separately, and the relative contributions of these pathways to $\mathrm{N}$ - and/P-induced changes in bacterial and fungal communities, however, have not been investigated using field experiments.

Subtropical forests in southern China undergo extensive $\mathrm{N}$ deposition with signs of $\mathrm{N}$ saturation, such as soil acidification (Zhu et al. 2015). Previous studies have demonstrated that forest productivity and soil respiration are sensitive to $\mathrm{N}$ and $\mathrm{P}$ enrichment, but little is known about how P addition affects microbial communities (Li et al. 2018a; Li et al. 2018b; Yu et al. 2017). To better understand the responses of bacterial and fungal communities to $\mathrm{N}$ and $\mathrm{P}$ 
106 addition and the underlying mechanisms, we conducted a $\mathrm{N}$ and $\mathrm{P}$ addition experiment in this

107 region. We specifically addressed the following questions: (1) How do bacterial / fungal taxa and

108 community structures respond to $\mathrm{N}$ and $\mathrm{P}$ enrichment? (2) How do soil biotic and abiotic factors

109 regulate the responses of bacterial / fungal taxa and community structures to $\mathrm{N}$ and $\mathrm{P}$

110 enrichment? Finally, (3) What are the mechanisms underlying shifts in bacterial / fungal taxa and

111 community structures to $\mathrm{N}$ and $\mathrm{P}$ enrichment?

\section{Materials \& Methods}

\section{Site description}

116 This nitrogen $(\mathrm{N})$ and phosphorus $(\mathrm{P})$ addition experiment was setup at the Jigongshan Nature

117 Reserve, China (31 $\left.51^{\prime} 58^{\prime \prime} \mathrm{N}, 114^{\circ} 5^{\prime} 12^{\prime \prime} \mathrm{E}\right)$. The site is experiencing northern subtropical to warm

118 temperate climates because it is located within a climate-transitional region. The mean annual

119 surface air temperature and mean annual rainfall at the reserve is $15.2^{\circ} \mathrm{C}$ and $1,118 \mathrm{~mm}$,

120 respectively. The soil type is yellow-brown and soil thickness is about 0.3-0.6 m (Yan et al.

121 2014). The forest type is deciduous oak mixed forest. The predominant tree species in the canopy

122 layer include Quercus acutissima and Q. variabilis and Liquidambar formosana, Lindera glauca,

123 and Viburnum dilatatum dominates the understory arborous layer. The age of the stand is about

$12445-50$ years and it is a secondary forest due to harvest in the late 1950s (Xu \& Liang 1965). The

125 total $\mathrm{N}$ deposition in this region is about $30 \mathrm{~kg} \mathrm{~N}^{-1} \mathrm{hr}^{-1}$ (Zhu et al. 2015). The soil properties

126 at the beginning of the experiment is listed in Table S1. 
128

129

130

131

132

133

134

135

136

137

138

139

140

141

142

143

144

145

146

147

\section{Experimental design}

The detailed information of $\mathrm{N}$ and $\mathrm{P}$ addition experiment could be found in previous studies (Li et al. 2018a; Li et al. 2018b). Briefly, this $\mathrm{N}$ and P addition experiment was setup in July 2013 using a complete randomized block design. Each block had four treatments that were randomly assigned to $10 \mathrm{~m} \times 10 \mathrm{~m}$ plots and four replicate blocks were established. Control $(\mathrm{CK}$, without $\mathrm{N}$ and $\mathrm{P}$ addition), $\mathrm{N}$ addition $\left(\mathrm{N}, 10 \mathrm{~g} \mathrm{~m}^{-2} \mathrm{yr}^{-1} \mathrm{NH}_{4} \mathrm{NO}_{3}\right), \mathrm{P}$ addition ( $\mathrm{P}, 10 \mathrm{~g} \mathrm{~m}^{-2} \mathrm{yr}^{-1}$ $\mathrm{NaH}_{2} \mathrm{PO}_{4}$ ), and $\mathrm{NP}$ addition (NP, $10 \mathrm{~g} \cdot \mathrm{m}^{-2} \cdot \mathrm{yr}^{-1} \mathrm{NH}_{4} \mathrm{NO}_{3}+10 \mathrm{~g} \cdot \mathrm{m}^{-2} \cdot \mathrm{yr}^{-1} \mathrm{NaH}_{2} \mathrm{PO}_{4}$ ) were included. Backpack sprayer were used to spray $50 \mathrm{~L}$ of water dissolved additions for each plot onto the forest floor monthly from May to October each year. The control plot received $50 \mathrm{~L}$ of water (equivalent to $0.5 \mathrm{~mm}$ precipitation) each time.

\section{Soil properties}

Six soil cores $(0-10 \mathrm{~cm}$ depth) were randomly collected from each plot and mixed to obtain one composite sample in October 2017. The samples were passed through a 2-mm sieve and three parts were divided. One part of the soil was used for the analysis of ammonium $\left(\mathrm{NH}_{4}^{+}\right)$, nitrate $\left(\mathrm{NO}_{3}{ }^{-}\right)$, microbial biomass carbon and nitrogen (MBC and $\left.\mathrm{MBN}\right)$, and dissolved organic carbon (DOC). The second part of fresh soil was collected in a 50-mL centrifuge tube, which was stored at $-80^{\circ} \mathrm{C}$ for soil DNA extraction. The remaining soil was air-dried for the determination of soil $\mathrm{pH}$, total soil organic carbon (SOC), total nitrogen (TN), available phosphorus (AP), and extractable cations including $\mathrm{Al}^{3+}, \mathrm{Ca}^{2+}, \mathrm{Mg}^{2+}$, and $\mathrm{Na}^{+}$. The plant fine roots collected from 6 soil cores using the $2 \mathrm{~mm}$-sieving were washed, dried, and then weighted. Soil ammonia and nitrate 
148

149

150

151

152

153

154

155

156

157

158

159

160

161

162

163

164

165

166

167

168

concentrations were determined by colorimetric analysis on a FIAstar 5000 Analyzer (FIAstar

5000 Analyzer, Foss Tecator, Hillerød, Denmark). Soil DOC was analyzed using a TOC

analyzer (multi N/C 3100, Analytik Jena, Germany). Soil MBC and MBN were determined by a

chloroform fumigation extraction method (Brookes et al. 1985). Soil pH was analyzed in a soil

water solution $(1: 2.5 \mathrm{w} / \mathrm{v}) . \mathrm{SOC}$ and $\mathrm{TN}$ were analyzed by a $\mathrm{C} / \mathrm{N}$ analyzer (vario EL III,

CHNOS Elemental Analyzer, Elementar, Germany). Available P was determined following by

molybdenum blue colorimetry (Jin et al. 2019). A modified extraction procedure was used to

measure extractable cations including $\mathrm{Al}^{3+}, \mathrm{Ca}^{2+}, \mathrm{Mg}^{2+}$, and $\mathrm{Na}^{+}$(Rauret et al. 2000).

\section{Soil DNA extraction, PCR amplification, and sequencing}

Soil DNA was extracted from each sample using a Fast DNA Stool Mini Kit (Tiangen Biotech

Beijing Co., Ltd., Beijing, China) according to the manufacturer's instructions. The quality of the

purified DNA was assessed based on the 260/280 $\mathrm{nm}$ and 260/230 $\mathrm{nm}$ absorbance ratios obtained

using a NanoDrop ND-1000 spectrophotometer (NanoDrop Technologies Inc., Wilmington, DE,

USA).

Microbial community diversity and composition were assessed by amplification of the $16 S$

$r R N A$ gene for the bacteria and the internal transcribed spacer (ITS) region of the fungi, as

described in Prober et al. (2015). Marker genes in the isolated DNA were PCR-amplified and

barcoded in triplicate reactions for both the $16 S r R N A$ gene (using the $515 \mathrm{f} / 907 \mathrm{r}$ primer pair) and

the ITS1 region (using the ITS1F/ITS2R primer pair). Sequencing was conducted on an Illumina

Miseq platform at Majorbio Biopharm Technology Co., Ltd., Shanghai, China.

Peer) reviewing PDF | (2019:04:36405:1:0:NEW 1 Aug 2019) 


\section{Sequencing data accession numbers}

170 Raw sequences were trimmed of reads containing ambiguous bases and long homopolymers and

171 merged using QIIME v 1.7.0 (Caporaso et al. 2012). All filtered sequences from 16S rRNA and

172 ITS gene amplicons were clusted into OTUs at 97\% similarity cutoff using UPARSE (version

173 7.1, http:// drive5.com/uparse), followed by chimera filtering usingn the Ribosomal Database

174 Project (RDP) (Tian et al. 2018) and UCHIME (Edgar et al. 2011). The bacterial and fungal

175 OTU sequences were classified using the RDP classifier against Greengenes and UNITE

176 reference database, repectively. All of the raw sequencing data (.fastq files) were submitted to

177 the Sequence Read Archive (SRA) at the National Center for Biotechnology Information (NCBI)

178 under accession number PRJNA531787

179 (https://www.ncbi.nlm.nih.gov/Traces/study/?acc=PRJNA531787).

180 Statistical analysis

181 The bacterial and fungal richness was determined by the number of OTUs, and alpha diversity

182 was estimated using the Shannon index. Linear regressions were applied to assess the

183 relationships between bacterial and fungal Shannon index and richness and environmental

184 factors. Stepwise multiple regressions were used to identify the most influential environmental

185 variables on bacterial and fungal Shannon index and richness due to collinearity among

186 environmental factors. Differences in microbial species richness, Shannon index, soil properties

187 and fine root biomass among different treatments were determined by one-way ANOVA with

188 Duncan test. To determine the effect size of N, P and combined NP treatment on the relative

189 abundances of the dominant bacterial and fungal taxa, the response ratio was calculated as $\ln$ 
$190\left(X_{t} / X_{c}\right)$, where $X_{t}$ is the mean value of experimental treatment and $X_{c}$ is the mean value of the

191 control treatment. One-sample t-test was used to estimate whether each response ratio was

192 significantly different from zero (She et al. 2018).

193 Principal component analysis (PCA) and nonmetric multidimensional scaling (NMDS) were

194 used to determine changes in the bacterial and fungal communities. Analyses, including Anosim,

195 Adonis, and MRPP, were further performed to assess the significant differences in community

196 among different treatments. The partial Mantel test was used to evaluate the linkages between

197 the microbial community structure and the environmental variables. Pairwise taxonomic distance

198 between microbial communities (Bray-Curtis) and Euclidean distance of environmental variables

199 were chosen for partial Mantel. PCA, NMDS, and partial Mantel were conducted using the

200 vegan package with $\mathrm{R}$ v3.5.0 (R Core Team 2018).

201 Structural equation modelling (SEM) was performed to analyze the hypothetical pathways

202 of $\mathrm{N}$ and $\mathrm{P}$ addition effects on bacterial and fungal diversity and community composition. Before

203 the SEM analysis, soil $\mathrm{N}$ availability including $\mathrm{NH}_{4}{ }^{+}$and $\mathrm{NO}_{3}{ }^{-}$, soil acid cations including $\mathrm{H}^{+}$

204 and $\mathrm{Al}^{3+}$, soil nutrients including SOC, TN, DOC, MBC and MBN, and microbial community

205 composition (OTUs) were subjected to principal component analysis (PCA) (Chen et al. 2013).

206 Soil N availability, soil acidity, soil nutrients, and microbial community composition were

207 presented by the first principal components (PC1) in the following SEM analysis. Maximum

208 likelihood estimation method was applied in the process of SEM. The goodness of the models

209 was determined by $\chi^{2}$ tests, Akaike information criteria (AIC), and root square mean errors of

210 approximation (RMSEA) (Li et al. 2018a).

PeerJ reviewing PDF | (2019:04:36405:1:0:NEW 1 Aug 2019) 


\section{Results}

\section{Fine root biomass and soil properties}

214 Nitrogen (N), phosphorus (P), and combined NP additions significantly reduced fine root

215 biomass (Table S2). Soil $\mathrm{pH}$ decreased with $\mathrm{N}$ addition, whereas $\mathrm{P}$ and NP additions did not have 216 any effect compared to the control. Soil $\mathrm{NH}_{4}{ }^{+}$was increased by $99.6 \%$ under $\mathrm{N}$ addition, whereas 217 it did not change after P and NP additions (Table S2). P and NP additions resulted in a 218 significant increase in soil available phosphorus (AP), but N addition did not (Table S2). Soil $219 \mathrm{Al}^{3+}$ increased by $57.4 \%, 27.0 \%$ and $59.1 \%$, respectively, under N, P and NP additions. Soil Ca $\mathrm{Ca}^{2+}$ decreased by $33.6 \%$ and $25.4 \%$, respectively, under N and NP additions, but did not significantly change under $\mathrm{P}$ addition. N, P, and NP additions did not significantly change soil organic carbon (SOC), total nitrogen $(\mathrm{TN})$, ratio of $\mathrm{SOC}$ to $\mathrm{TN}(\mathrm{C} / \mathrm{N}$ ratio), dissolved organic carbon (DOC), microbial biomass carbon, and nitrogen (MBC and $\mathrm{MBN}$ ), $\mathrm{NO}_{3}{ }^{-}, \mathrm{Mg}^{2+}$, and $\mathrm{Na}^{+}$.

\section{Relative abundance of dominant microbial taxa}

16,573 to 26,745 (average: 21,019 ) and 46,414-70,354 (average: 64,655) valid sequences were consequently obtained per sample for bacterial and fungi, respectively. These sequences were grouped into 1,666 and 2,487 OTUs at the 97\% similarity level for bacterial and fungi, respectively. All of the samples were compared at an equivalent sequencing depth of 16,573 and 46,414 per sample for bacteria and fungi, respectively. 
The predominant bacterial phyla across all of the samples were Proteobacteria,

232 233

234 235 236

237 238 239

Acidobacteria, and Actinobacteria (mean relative abundance $>5 \%$ ), which accounted for more than $82 \%$ of the bacterial sequences on average (Fig. 1a). In addition, Planctomycetes,

Chloroflexi, Firmicutes, Bacteroidetes, and Gemmatimonadetes were also present at relatively low abundance. The dominant fungal phyla across all of the samples were Ascomycota, Basidiomycota, Zygomycota, and Rozellomycota (Fig. 1b).

At the phylum level, Omnitrophica, Chlorobi, and Nitrospirae presented significant decrease and Saccharibacteria increased in relative abundance under $\mathrm{N}$ treatment (Fig. 2a). P addition significantly increased the relative abundances of Elusimicrobia, but $\mathrm{N}$ addition had no effect compared to the control plots (Fig. 2a). Only NP treatment increased the relative abundance of Firmicutes and decreased that of Chloroflexi (Fig. 2a). No significant differences were observed in the fungal relative abundance of Ascomycota, Rozellomycota, and Chytridiomycota at the phylum level among different treatments (Figs. 2b). Basidiomycota presented significant decrease in their relative abundance under N and NP additions and only NP addition decreased the relative abundance of Zygomycota (Fig. 2b). At the fungal genus level, Chaetomium and Purpureocillium presented significant decrease in their relative abundance under $\mathrm{N}$ and $\mathrm{P}$ treatments, and $\mathrm{N}$ and NP treatments decreased the relative abundance of Mycoarthris (Fig. 2b). The relative abundance of Mortierella significantly decreased only under NP addition (Fig. 2b).

\section{Bacterial and fungal $\alpha$ diversity}


$252 \mathrm{~N}$ addition significantly decreased bacterial $\alpha$ diversity, including phylotype richness (OTU

253 numbers) and Shannon diversity index, but did not change fungal $\alpha$ diversity (Fig. 3). P addition

254 had no effect on both bacterial and fungal $\alpha$ diversity. NP addition only decreased fungal

255 phylotype richness (Fig. 3). $\mathrm{N}$ addition decreased the number of unique phylotypes compared to

256 the control (Table S3).

257 The bacterial richness exhibited the largest correlation with soil $\mathrm{pH}$ among all of the

258 environmental factors (Table $1, r=0.80, P<0.01)$. In addition to DOC $(r=-0.72, P<0.01)$, soil

$259 \mathrm{pH}$ was the best predictor of bacterial diversity (Table $1, r=0.71, P<0.01$ ). Bacterial richness

260 and diversity also significantly correlated with fine root biomass, $\mathrm{SOC}, \mathrm{MBC}, \mathrm{Al}^{3+}$, and $\mathrm{Ca}^{2+}$

261 (Table 1). Soil $\mathrm{Al}^{3+}(r=-0.62, P<0.05)$ presented the largest correlation with fungal richness,

262 followed by soil $\mathrm{pH}(r=0.57, P<0.05)$. No significant correlations were noted between fungal

263 diversity and any of the environmental variables (Table 1).

264 Stepwise regression showed that bacterial richness significantly correlated with $\mathrm{pH}(64.3 \%)$

265 and DOC (7.1\%) (Table S4). Soil $\mathrm{pH}$ explained the largest part of the variation in bacterial

266 diversity (50.1\%), followed by TN (14.9\%), DOC (13.4\%), and MBC (9.7\%). Soil pH explained

$26733.0 \%$ of the variation in fungal richness, whereas $\mathrm{pH}(17.0 \%)$, SOC (19.1\%), and MBC (41.4\%)

268 collectively contributed to $65.2 \%$ of the variation in fungal diversity (Table S4).

269

270 Bacterial and fungal community structure and relationships with environmental factors

271 Significant differences in bacterial community structure between N and NP additions and the

272 control were observed in NMDS and PCA plots (Figs. 4 and S1). However, only NP addition 
273 exhibited significant differences in fungal community structure compared to the control (Fig. 4).

274 The results of ANOSIM, ADONIS, and MRPP analyses further confirmed the significant

275 differences among treatments (Table S5). This finding was confirmed by a cluster analysis based

276 on a Bray-Curtis distance matrix of soil samples under different treatments (Fig. S2).

277 A partial Mantel test was performed to reveal the major environmental variables shaping

278 microbial community structure. $\mathrm{pH}\left(r_{\mathrm{M}}=0.57, P=0.001\right), \mathrm{Al}^{3+}\left(r_{\mathrm{M}}=0.40, P=0.002\right)$ and fine

279 root biomass $\left(r_{\mathrm{M}}=0.36, P=0.005\right)$ were the most important factors that independently

280 contributed to variations in soil bacterial community structure (Table 2). TN, C:N ratio, DOC,

281 and MBC showed weak but significant correlations $\left(r_{\mathrm{M}}=0.21, r_{\mathrm{M}}=0.22, r_{\mathrm{M}}=0.27, r_{\mathrm{M}}=0.24\right.$,

282 respectively, $P<0.05)$ (Table 2$). \mathrm{pH}\left(r_{\mathrm{M}}=0.57, P=0.001\right)$ and $\mathrm{MBC}\left(r_{\mathrm{M}}=0.40, P=0.004\right)$

283 were the most important factors that independently contributed to variations in soil fungal

284 community structure (Table 2). C:N ratio, $\mathrm{DOC}, \mathrm{Al}^{3+}$, and $\mathrm{Mg}^{2+}$ showed weak but significant

285 correlations $\left(r_{\mathrm{M}}=0.25, r_{\mathrm{M}}=0.26, r_{\mathrm{M}}=0.21, r_{\mathrm{M}}=0.27\right.$, respectively, $\left.P<0.05\right)$ (Table 2$)$.

The SEM explained $12 \%$ of the variations in soil $\mathrm{N}$ availability, $83 \%$ of the variation in soil acid cations $\left(\mathrm{H}^{+}\right.$and $\left.\mathrm{Al}^{3+}\right), 5 \%$ of the variation in soil nutrients and $80 \%$ of the variation in soil available P (Fig. 5). The total variation in bacterial Shannon index was mainly explained (64\%) by soil acid cations and soil available P (Fig. 5a), but the total variation in fungal Shannon index was mainly explained (39\%) by soil available $\mathrm{P}$ (marginally significant, $P=0.08$, Fig. $5 \mathrm{~b}$ ). The 
294

295

296

297

298

299

300

301

302

303

304

305

306

307

\section{Discussion}

total variation in bacterial community composition was mainly explained (79\%) by soil acid cations (Fig. 5a), but the total variation in fungal community composition was mainly explained (45\%) by soil nutrients (Fig. 5b). Linear regression demonstrated that principal component (PC1) scores of fungal community composition was significantly correlated with PC1 scores of soil nutrients $\left(\mathrm{R}^{2}=0.41, P=0.008\right.$, Fig. S3).

Standardized total effects from SEM demonstrated that N enrichment had stronger effects on bacterial diversity and community composition compared to P addition (Fig. 6). Specifically, acid cations showed the most powerful negative effect on bacterial diversity (Fig. 6a) and had a stronger positive effect on bacterial community composition than soil $\mathrm{N}$ availability (Fig. 6b). Both $\mathrm{N}$ and $\mathrm{P}$ enrichment had negative effects on fungal diversity, and soil nutrients exerted the most powerful positive effect on fungal diversity (Fig. 6c). $\mathrm{N}$ enrichment had stronger positive effects on fungal community composition, and soil nutrients exerted strongest negative effect on fungal community composition (Fig. 6d).

\section{$\mathrm{N}$ but not $\mathbf{P}$ addition significantly influences bacterial communities}

Our results showed that $\mathrm{N}$ addition significantly decreased bacterial OTU richness and Shannon index and altered the bacterial community composition, with Saccharibacteria increasing, but Chloroflex decreasing in terms of their relative abundances (Figs. 2-4, Table S5). These results indicate that $\mathrm{N}$ addition tends to favor the copiotrophic phylum (Saccharibacteria) and counterselects the oligotrophic phylum (Chloroflex) in bacterial communities, which is in line 
315 with the copiotrophic hypothesis in previous reports (Fierer et al. 2007; Fierer et al. 2012; Leff et

316 al. 2015). However, $\mathrm{N}$ addition did not change the relative abundance of dominant phylum of

317 Proteobacteria, Acidobacteria, and Actinobacteria (Fig. 2). The results are in contrast with the

318 findings of previous studies, which showed that added $\mathrm{N}$ stimulates and decreases the relative

319 abundances of Proteobacteria (copiotrophic) and Acidobacteria (oligotrophic), respectively

320 (Chen et al. 2019; Fierer et al. 2012; Leff et al. 2015). This discrepancy could be attributable to

321 neutral effects of $\mathrm{N}$ enrichment on soil available $\mathrm{C}$ and $\mathrm{N}$ (including DOC and $\mathrm{NO}_{3}^{-}$, Table $\mathrm{S} 2$ )

322 (Turlapati et al. 2013). It has been well documented that Proteobacteria contains N-fixing and N

323 transforming genera (e.g., Bradyrhizobium, Burkholderia, Magnetospirillum, and

324 Mesorhizobium) and thus are closely related to N cycling. However, in our study, added N only

325 increased $\mathrm{NH}_{4}{ }^{+}$and did not affect $\mathrm{NO}_{3}{ }^{-}$, indicating the $\mathrm{N}$ transforming-related bacterial phylum

326 (Proteobacteria) may not be affected by the addition of N. Additionally, Acidobacteria has been

327 reported to be negatively correlated with soil C availability (Fierer et al. 2007). The neutral effect

328 of elevated $\mathrm{N}$ on DOC in our study may have contributed to the unaltered relative abundance of

329 Acidobacteria, which is favored by low C availability (Fierer et al. 2007; Turlapati et al. 2013).

330 Finally, the absence of a decrease in the abundance of Actinobacteria may be attributed to its

331 relatively high tolerance to environmental stress such as low pH (Dai et al. 2018).

332 In contrast to most previous findings (Ling et al. 2017; Tan et al. 2013), neither the bacterial

333 diversity nor the community composition was substantially influenced by $\mathrm{P}$ addition in our study

334 (Figs. 3-4, Table S5), but this finding is consistent with a previous study reporting that most

335 bacterial taxa were not limited by $\mathrm{P}$ in Tibetan meadow (Ma et al. 2019). Among all of the 
336 bacterial phyla identified, only Elusimicrobia were negatively correlated with soil available P

337 (Table S6). There are several potential explanations for the insensitive response to added P. First,

338 it is well established that nutrient addition-induced $\mathrm{pH}$ decline is an important mechanism in

339 shifting the bacterial community composition (Chen et al. 2015; Ling et al. 2017; Zeng et al.

340 2016). However, $\mathrm{P}$ addition did not change the soil $\mathrm{pH}$ in our study (Table S2). Additionally, $\mathrm{P}$

341 input could increase the $\mathrm{P}$ availability, and thus affect the bacterial richness and community

342 structure, especially in P-limited ecosystems (Li et al. 2015; Liu et al. 2013). Our results showed

343 that increased soil P availability did not change microbial biomass, suggesting that microbial

344 growth is not limited to $\mathrm{P}$ in this subtropical forest. Finally, Liu et al. (2013) pointed out that a

345 decrease in labile SOC is associated with alterations in soil microbial community structure under

346 P addition. In our study, however, neither SOC or DOC was not significantly influenced by P

347 addition (Table S2). Overall, our results suggest that only increased P availability may not be

348 able to change the bacterial community composition in subtropical forest.

349 Neither $\mathbf{N}$ nor $\mathbf{P}$ addition significantly influenced fungal community

350 Our results demonstrated that fungal OTU richness is positively correlated to fine root biomass

351 and soil $\mathrm{pH}$ and negatively related to $\mathrm{MBC}$ and soil $\mathrm{Al}^{3+}$. However, fungal Shannon index was

352 not significantly associated with soil parameters (Table 1). Fungal community structure was

353 closely related to soil $\mathrm{pH}$ and $\mathrm{MBC}$, followed by soil $\mathrm{C}: \mathrm{N}$ ratio, $\mathrm{DOC}, \mathrm{Al}^{3+}$, and $\mathrm{Mg}^{2+}$ (Table 2).

354 In contrast to the bacterial community, both $\mathrm{N}$ and $\mathrm{P}$ additions did not significantly change

355 fungal richness and diversity (Fig. 3), which suggests that the tolerances of fungi to

356 environmental changes are generally stronger than those of bacteria (Fierer et al. 2012; Rousk et 
357 al. 2010). The responses of fungal diversity to $\mathrm{N}$ enrichment is not always consistent due to

358 ecosystem type and nutrient dose (Chen et al. 2019; Mueller et al. 2014). Some studies have

359 demonstrated that experimental $\mathrm{N}$ deposition results in increased fungal richness and diversity in

360 a low fertility loblolly pine forest (Mueller et al. 2014; Weber et al. 2013), but other studies

361 showed the opposite response partly due to variations in nutrient availability (Chen et al. 2019;

362 Chen et al. 2018a). Previous studies have demonstrated that $\mathrm{N}$ enrichment increases the relative

363 abundance of copiotrophic phylum Ascomycota and decreased that of oligotrophic phylum

364 Basidiomycota according to the copiotroph-oligotroph concept (Chen et al. 2018b; Fierer et al.

365 2007; She et al. 2018; Yao et al. 2017). Although no significant effect of $\mathrm{N}$ enrichment on fungal

366 community composition was observed (Fig. 4, Table S5), regression analysis also showed that

367 the relative abundance of Basidiomycota was negatively correlated with soil $\mathrm{N}$ availability $\left(\mathrm{NH}_{4}{ }^{+}\right.$

368 and $\mathrm{NO}_{3}^{-}$, Table $\mathrm{S} 6$ ), indicating that $\mathrm{N}$ enrichment likely directly affects Basidiomycota via

369 increasing $\mathrm{N}$ availability. Overall, the limited responses of fungal richness, diversity, and

370 community composition under $\mathrm{N}$ enrichment in our study may be due to increased $\mathrm{N}$ loss from

371 soil through denitrification and leaching (Niu et al. 2016).

372 Compared to many studies analyzing the response of soil microorganisms to $\mathrm{N}$ addition,

373 relatively little research has been done on the effects of $\mathrm{P}$ enrichment on soil fungi in grasslands

374 and forests (Li et al. 2015; Liu et al. 2013), and much fewer studies using high-resolution

375 technology, such as $16 S r R N A$ sequencing (Cassman et al. 2016; He et al. 2016). The

376 understanding of fungal community responses to elevated P inputs remains limited (Leff et al.

377 2015). The effect of $P$ addition on soil fungal community composition depends on ecosystem 
378 type, soil properties, and nutrient type and dose (Bao et al. 2013; Beauregard et al. 2010; Li et al.

379 2015; Liu et al. 2013). Previous studies have demonstrated that experimental P fertilization

380 reduces the species richness of arbuscular mycorrhizal fungi, which could increase soil nutrient

381 capture of their hosts in return for plant C resource (Camenzind et al. 2014; Cheng et al. 2013;

382 Liu et al. 2013). However, elevated P input could alleviate P deficiency of soil microbes and

383 increase the fungal biomass, suggesting $\mathrm{P}$ availability is one of the limiting factors for fungal

384 growth in an old tropical forest (Liu et al. 2012a). Another explanation for the not significant

385 change of fungal community composition in response to $\mathrm{P}$ enrichment might be the relatively

386 short-term experimental duration of $\mathrm{P}$ addition (Cheng et al. 2013), and these detailed parameters

387 on fungal community composition warrant further investigation.

388 Mechanisms underlying responses of soil bacterial and fungal communities to $\mathbf{N}$ and $\mathbf{P}$

389 inputs

390 Several mechanisms behind the observed shift of bacterial and fungal community composition

391 under $\mathrm{N}$ and $\mathrm{P}$ additions have been proposed, including increased $\mathrm{N}$ and $\mathrm{P}$ availability (Liu et al.

392 2012a; Liu et al. 2013; Nie et al. 2018; Zhou et al. 2017), a decline in soil pH (Chen et al. 2015;

393 Zeng et al. 2016), and increased soil acid cations availability (Chen et al. 2015). Contrary to the

$394 \mathrm{~N}$ and P availability theory (Liu et al. 2012a; Nie et al. 2018), our results showed that $\mathrm{N}$ and P

395 availability (including $\mathrm{NH}_{4}^{+}, \mathrm{NO}_{3}{ }^{-}$, and AP) had no significant relationship with bacterial and

396 fungal diversity and community structure (Table 1 and 2). Meanwhile, both partial Mantel test

397 and SEM results have demonstrated that $\mathrm{N}$ and $\mathrm{P}$ availability had no significant relationship with

398 bacterial and fungal community composition (Table 2, Fig. 5), suggesting that $\mathrm{N}$ and $\mathrm{P}$

Peer] reviewing PDF | (2019:04:36405:1:0:NEW 1 Aug 2019) 
399 availability could not explain the shifts in bacterial and fungal community composition. The

400 remaining possible reasons for the decline of bacterial diversity and shift of bacterial community

401 composition include increased concentration of $\mathrm{H}^{+}$and $\mathrm{Al}^{3+}$ (Table S2). Furthermore, SEM

402 results showed that soil acid cations $\left(\mathrm{H}^{+}\right.$and $\left.\mathrm{Al}^{3+}\right)$ induced a significant decrease in bacterial

403 diversity and substantial change of bacterial community composition (Figs 5, 6). However, SEM

404 results have demonstrated that soil nutrients are significantly correlated to fungal community

405 composition (Fig. 5). Taken together, in this study, increase of soil acid cations and soil nutrients

406 significantly contributed to the shift in bacterial and fungal community composition,

407 respectively.

408

\section{Conclusions}

410 After a five-year $\mathrm{N}$ and $\mathrm{P}$ addition in subtropical forest, our results showed that $\mathrm{N}$ addition

411 significantly decreased bacterial species richness and diversity, and resulted in a substantial shift

412 of bacterial community composition, whereas $\mathrm{P}$ addition did not. Neither $\mathrm{N}$ nor $\mathrm{P}$ addition

413 changed fungal species richness, diversity, and fungal community composition. A structural

414 equation model showed that the shift in bacterial community composition is attributable to an

415 increase in soil acid cations. The principal component scores of soil nutrients showed a

416 significantly positive relationship with fungal community composition. Our results show how the

417 diversity of microbial communities of subtropical forest soil will depend on future scenarios of

418 anthropogenic $\mathrm{N}$ deposition and $\mathrm{P}$ enrichment, with a particular sensitivity of bacterial

419 community to $\mathrm{N}$ addition 


\section{Acknowledgements}

422 The authors would like to thank the staffs from Jigongshan Natural Reserve for experimental site 423 setup and data collection. Two reviewers and academic editor Xavier Le Roux are appreciated 424 for their constructive comments and valuable inputs.

425

426

\section{7}

428

429

430

431

432

433

434

435

436

437

438

439

440

441

442

443

444

445

446

447

448

449

450

451

452

453

\section{References}

Bao Z, Matsushita Y, Morimoto S, Hoshino YT, Suzuki C, Nagaoka K, Takenaka M, Murakami H, Kuroyanagi Y, Urashima Y, Sekiguchi H, Kushida A, Toyota K, Saito M, and Tsushima S. 2013. Decrease in fungal biodiversity along an available phosphorous gradient in arable Andosol soils in Japan. Canadian Journal of Microbiology 59:368-373. 10.1139/cjm2012-0612

Beauregard MS, Hamel C, Atul N, and St-Arnaud M. 2010. Long-term phosphorus fertilization impacts soil fungal and bacterial diversity but not AM fungal community in Alfalfa. Microbial Ecology 59:379-389. 10.1007/s00248-009-9583-z

Bowman WD, Cleveland CC, Halada L, Hresko J, and Baron JS. 2008. Negative impact of nitrogen deposition on soil buffering capacity. Nature Geoscience 1:767-770.

Brookes PC, Landman A, Pruden G, and Jenkinson DS. 1985. Chloroform fumigation and the release of soil nitrogen: $A$ rapid direct extraction method to measure microbial biomass nitrogen in soil. Soil Biology and Biochemistry 17:837-842. http://dx.doi.org/10.1016/0038-0717(85)90144-0

Camenzind T, Hempel S, Homeier J, Horn S, Velescu A, Wilcke W, and Rillig MC. 2014. Nitrogen and phosphorus additions impact arbuscular mycorrhizal abundance and molecular diversity in a tropical montane forest. Global Change Biology 20:3646-3659. doi:10.1111/gcb.12618

Caporaso JG, Lauber CL, Walters WA, Berg-Lyons D, Huntley J, Fierer N, Owens SM, Betley J, Fraser L, Bauer M, Gormley N, Gilbert JA, Smith G, and Knight R. 2012. Ultra-highthroughput microbial community analysis on the Illumina HiSeq and MiSeq platforms. ISME J 6:1621-1624. 10.1038/ismej.2012.8

Cassman NA, Leite MFA, Pan Y, de Hollander M, van Veen JA, and Kuramae EE. 2016. Plant and soil fungal but not soil bacterial communities are linked in long-term fertilized grassland. Scientific Reports 6:23680. 10.1038/srep23680 
454

455

456

457

458

459

460

461

462

463

464

465

466

467

468

469

470

471

472

473

474

475

476

477

478

479

480

481

482

483

484

485

486

487

488

489

490

491

492

493

494

https://www.nature.com/articles/srep23680\#supplementary-information

Chen D, Lan Z, Bai X, Grace JB, and Bai Y. 2013. Evidence that acidification-induced declines in plant diversity and productivity are mediated by changes in below-ground communities and soil properties in a semi-arid steppe. Journal of Ecology 101:1322-1334. 10.1111/1365-2745.12119

Chen D, Lan Z, Hu S, and Bai Y. 2015. Effects of nitrogen enrichment on belowground communities in grassland: Relative role of soil nitrogen availability vs. soil acidification. Soil Biology and Biochemistry 89:99-108. http://dx.doi.org/10.1016/j.soilbio.2015.06.028

Chen D, Li J, Lan Z, Hu S, and Bai Y. 2016. Soil acidification exerts a greater control on soil respiration than soil nitrogen availability in grasslands subjected to long-term nitrogen enrichment. Functional Ecology 30:658-669. 10.1111/1365-2435.12525

Chen D, Xing W, Lan Z, Saleem M, Wu Y, Hu S, and Bai Y. 2019. Direct and indirect effects of nitrogen enrichment on soil organisms and carbon and nitrogen mineralization in a semiarid grassland. Functional Ecology 33:175-187. doi:10.1111/1365-2435.13226

Chen W, Xu R, Chen J, Yuan X, Zhou L, Tan T, Fan J, Zhang Y, and Hu T. 2018a. Consistent responses of surface- and subsurface soil fungal diversity to $\mathrm{N}$ enrichment are mediated differently by acidification and plant community in a semi-arid grassland. Soil Biology and Biochemistry 127:110-119. https://doi.org/10.1016/j.soilbio.2018.09.020

Chen W, Xu R, Wu Y, Chen J, Zhang Y, Hu T, Yuan X, Zhou L, Tan T, and Fan J. 2018b. Plant diversity is coupled with beta not alpha diversity of soil fungal communities following $\mathrm{N}$ enrichment in a semi-arid grassland. Soil Biology and Biochemistry 116:388-398. https://doi.org/10.1016/j.soilbio.2017.10.039

Cheng Y, Ishimoto K, Kuriyama Y, Osaki M, and Ezawa T. 2013. Ninety-year-, but not single, application of phosphorus fertilizer has a major impact on arbuscular mycorrhizal fungal communities. Plant and Soil 365:397-407. 10.1007/s11104-012-1398-x

Dai Z, Su W, Chen H, Barberán A, Zhao H, Yu M, Yu L, Brookes PC, Schadt CW, Chang SX, and $\mathrm{Xu}$ J. 2018. Long-term nitrogen fertilization decreases bacterial diversity and favors the growth of Actinobacteria and Proteobacteria in agro-ecosystems across the globe. Global Change Biology 24:3452-3461. doi:10.1111/gcb.14163

DeForest JL, and Scott LG. 2010. Available organic soil phosphorus has an important influence on microbial community composition. Soil Science Society of America Journal 74:20592066. 10.2136/sssaj2009.0426

Edgar RC, Haas BJ, Clemente JC, Quince C, and Knight R. 2011. UCHIME improves sensitivity and speed of chimera detection. Bioinformatics (Oxford, England) 27:2194-2200. 10.1093/bioinformatics/btr381

Fierer N, Bradford MA, and Jackson RB. 2007. Toward an ecological classification of soil bacteria. Ecology 88:1354-1364. 10.1890/05-1839

Fierer N, Lauber CL, Ramirez KS, Zaneveld J, Bradford MA, and Knight R. 2012. Comparative metagenomic, phylogenetic and physiological analyses of soil microbial communities across $\quad$ nitrogen gradients. ISME $\quad J$ b:1007-1017. http://www.nature.com/ismej/journal/v6/n5/suppinfo/ismej2011159s1.html 
495

496

497

498

499

500

501

502

503

504

505

506

507

508

509

510

511

512

513

514

515

516

517

518

519

520

521

522

523

524

525

526

527

528

529

530

531

532

533

534

535

Galloway JN, Townsend AR, Erisman JW, Bekunda M, Cai Z, Freney JR, Martinelli LA, Seitzinger SP, and Sutton MA. 2008. Transformation of the nitrogen cycle:recent trends, questions, and potential solutions. Science 320:889-892. 10.1126/science.1136674

Guo JH, Liu XJ, Zhang Y, Shen JL, Han WX, Zhang WF, Christie P, Goulding KWT, Vitousek PM, and Zhang FS. 2010. Significant acidification in major Chinese croplands. Science 327:1008-1010. 10.1126/science.1182570

Harpole WS, Ngai JT, Cleland EE, Seabloom EW, Borer ET, Bracken MES, Elser JJ, Gruner DS, Hillebrand $\mathrm{H}$, Shurin JB, and Smith JE. 2011. Nutrient co-limitation of primary producer communities. Ecology Letters 14:852-862. 10.1111/j.1461-0248.2011.01651.x

He D, Xiang X, He J-S, Wang C, Cao G, Adams J, and Chu H. 2016. Composition of the soil fungal community is more sensitive to phosphorus than nitrogen addition in the alpine meadow on the Qinghai-Tibetan Plateau. Biology and Fertility of Soils 52:1059-1072. 10.1007/s00374-016-1142-4

Hooper DU, Adair EC, Cardinale BJ, Byrnes JEK, Hungate BA, Matulich KL, Gonzalez A, Duffy JE, Gamfeldt L, and O/'Connor MI. 2012. A global synthesis reveals biodiversity loss as a major driver of ecosystem change. Nature 486:105-108. http://www.nature.com/nature/journal/v486/n7401/abs/nature11118.html\#supplementaryinformation

Isbell F, Reich PB, Tilman D, Hobbie SE, Polasky S, and Binder S. 2013. Nutrient enrichment, biodiversity loss, and consequent declines in ecosystem productivity. Proceedings of the National Academy of Sciences of the United States of America 110:11911-11916. 10.1073/pnas.1310880110 \%J Proceedings of the National Academy of Sciences

Jin Z, Chen C, Chen X, Hopkins I, Zhang X, Han Z, Jiang F, and Billy G. 2019. The crucial factors of soil fertility and rapeseed yield - A five year field trial with biochar addition in upland red soil, China. Science of the Total Environment 649:1467-1480. https://doi.org/10.1016/j.scitotenv.2018.08.412

Jorquera MA, Martínez OA, Marileo LG, Acuña JJ, Saggar S, and Mora ML. 2014. Effect of nitrogen and phosphorus fertilization on the composition of rhizobacterial communities of two Chilean Andisol pastures. World Journal of Microbiology and Biotechnology 30:99107. 10.1007/s11274-013-1427-9

Lagos LM, Acuña JJ, Maruyama F, Ogram A, de la Luz Mora M, and Jorquera MA. 2016. Effect of phosphorus addition on total and alkaline phosphomonoesterase-harboring bacterial populations in ryegrass rhizosphere microsites. Biology and Fertility of Soils 52:10071019. 10.1007/s00374-016-1137-1

Lauber CL, Hamady M, Knight R, and Fierer N. 2009. Pyrosequencing-based assessment of soil $\mathrm{pH}$ as a predictor of soil bacterial community structure at the continental scale. 75:51115120. 10.1128/AEM.00335-09 \%J Applied and Environmental Microbiology

LeBauer DS, and Treseder KK. 2008. Nitrogen limitation of net primary productivity in terrestrial ecosystems in globally distributed. Ecology 89:371-379. 10.1890/06-2057.1

Leff JW, Jones SE, Prober SM, Barberan A, Borer ET, Firn JL, Harpole WS, Hobbie SE, Hofmockel KS, Knops JMH, McCulley RL, La Pierre K, Risch AC, Seabloom EW, 
536

537

538

539

540

541

542

543

544

545

546

547

548

549

550

551

552

553

554

555

556

557

558

559

560

561

562

563

564

565

566

567

568

569

570

571

572

573

574

575

576

Schuetz M, Steenbock C, Stevens CJ, and Fierer N. 2015. Consistent responses of soil microbial communities to elevated nutrient inputs in grasslands across the globe. Proceedings of the National Academy of Sciences of the United States of America 112:10967-10972. 10.1073/pnas.1508382112

Li J, Li Z, Wang F, Zou B, Chen Y, Zhao J, Mo Q, Li Y, Li X, and Xia H. 2015. Effects of nitrogen and phosphorus addition on soil microbial community in a secondary tropical forest of China. Biology and Fertility of Soils 51:207-215. 10.1007/s00374-014-0964-1

Li Y, Niu S, and Yu G. 2016. Aggravated phosphorus limitation on biomass production under increasing nitrogen loading: a meta-analysis. Global Change Biology 22:934-943. 10.1111/gcb.13125

Li Y, Sun J, Tian D, Wang J, Ha D, Qu Y, Jing G, and Niu S. 2018a. Soil acid cations induced reduction in soil respiration under nitrogen enrichment and soil acidification. Science of the Total Environment 615:1535-1546. https://doi.org/10.1016/j.scitotenv.2017.09.131

Li Y, Tian D, Yang H, and Niu S. 2018b. Size-dependent nutrient limitation of tree growth from subtropical to cold temperate forests. Functional Ecology 32:95-105. 10.1111/13652435.12975

Ling N, Chen D, Guo H, Wei J, Bai Y, Shen Q, and Hu S. 2017. Differential responses of soil bacterial communities to long-term $\mathrm{N}$ and $\mathrm{P}$ inputs in a semi-arid steppe. Geoderma 292:25-33. https://doi.org/10.1016/j.geoderma.2017.01.013

Liu L, Gundersen P, Zhang T, and Mo J. 2012a. Effects of phosphorus addition on soil microbial biomass and community composition in three forest types in tropical China. Soil Biology and Biochemistry 44:31-38. http://dx.doi.org/10.1016/j.soilbio.2011.08.017

Liu L, Zhang T, Gilliam FS, Gundersen P, Zhang W, Chen H, and Mo JM. 2013. Interactive effects of nitrogen and phosphorus on soil microbial communities in a tropical forest. PloS One 8. 10.1371/journal.pone.0061188

Liu Y, Shi G, Mao L, Cheng G, Jiang S, Ma X, An L, Du G, Johnson NC, and Feng H. 2012b. Direct and indirect influences of $8 \mathrm{yr}$ of nitrogen and phosphorus fertilization on Glomeromycota in an alpine meadow ecosystem. New Phytologist 194:523-535. doi:10.1111/j.1469-8137.2012.04050.x

Ma B, Zhou X, Zhang Q, Qin M, Hu L, Yang K, Xie Z, Ma W, Chen B, Feng H, Liu Y, Du G, Ma X, and Le Roux X. 2019. How do soil micro-organisms respond to N, P and NP additions? Application of the ecological framework of (co-)limitation by multiple resources. Journal of Ecology. 10.1111/1365-2745.13179

Ma W, Jiang S, Assemien F, Qin M, Ma B, Xie Z, Liu Y, Feng H, Du G, Ma X, and Le Roux X. 2016. Response of microbial functional groups involved in soil $N$ cycle to $N, P$ and NP fertilization in Tibetan alpine meadows. Soil Biology and Biochemistry 101:195-206. https://doi.org/10.1016/j.soilbio.2016.07.023

Mao Q, Lu X, Zhou K, Chen H, Zhu X, Mori T, and Mo J. 2017. Effects of long-term nitrogen and phosphorus additions on soil acidification in an N-rich tropical forest. Geoderma 285:5763. https://doi.org/10.1016/j.geoderma.2016.09.017

Mueller RC, Balasch MM, and Kuske CR. 2014. Contrasting soil fungal community responses to 
577

578

579

580

581

582

583

584

585

586

587

588

589

590

591

592

593

594

595

596

597

598

599

600

601

602

603

604

605

606

607

608

609

610

611

612

613

614

615

616

617

experimental nitrogen addition using the large subunit rRNA taxonomic marker and cellobiohydrolase I functional marker. Molecular Ecology 23:4406-4417. doi:10.1111/mec.12858

Nie Y, Wang M, Zhang W, Ni Z, Hashidoko Y, and Shen W. 2018. Ammonium nitrogen content is a dominant predictor of bacterial community composition in an acidic forest soil with exogenous nitrogen enrichment. Science of the Total Environment 624:407-415. https://doi.org/10.1016/j.scitotenv.2017.12.142

Niu S, Classen AT, Dukes JS, Kardol P, Liu L, Luo Y, Rustad L, Sun J, Tang J, Templer PH, Thomas RQ, Tian D, Vicca S, Wang Y-P, Xia J, and Zaehle S. 2016. Global patterns and substrate-based mechanisms of the terrestrial nitrogen cycle. Ecology Letters 19:697709. 10.1111/ele.12591

Peñuelas J, Poulter B, Sardans J, Ciais P, van der Velde M, Bopp L, Boucher O, Godderis Y, Hinsinger P, Llusia J, Nardin E, Vicca S, Obersteiner M, and Janssens IA. 2013. Humaninduced nitrogen-phosphorus imbalances alter natural and managed ecosystems across the globe. Nature Communications 4:2934. 10.1038/ncomms3934

Prober SM, Leff JW, Bates ST, Borer ET, Firn J, Harpole WS, Lind EM, Seabloom EW, Adler PB, Bakker JD, Cleland EE, DeCrappeo NM, DeLorenze E, Hagenah N, Hautier Y, Hofmockel KS, Kirkman KP, Knops JMH, La Pierre KJ, MacDougall AS, McCulley RL, Mitchell CE, Risch AC, Schuetz M, Stevens CJ, Williams RJ, and Fierer N. 2015. Plant diversity predicts beta but not alpha diversity of soil microbes across grasslands worldwide. Ecology Letters 18:85-95. 10.1111/ele.12381

R Core Team. 2018. R: A Language and Environment for Statistical Computing. R Foundation for Statistical Computing, Vienna, Austria URL https://wwwR-projectorg/.

Ramirez KS, Craine JM, and Fierer N. 2012. Consistent effects of nitrogen amendments on soil microbial communities and processes across biomes. Global Change Biology 18:19181927. 10.1111/j.1365-2486.2012.02639.x

Rauret G, Lopez-Sanchez JF, Sahuquillo A, Barahona E, Lachica M, Ure AM, Davidson CM, Gomez A, Luck D, Bacon J, Yli-Halla M, Muntau H, and Quevauviller P. 2000. Application of a modified BCR sequential extraction (three-step) procedure for the determination of extractable trace metal contents in a sewage sludge amended soil reference material (CRM 483), complemented by a three-year stability study of acetic acid and EDTA extractable metal content. Journal of Environmental Monitoring 2:228-233. 10.1039/B001496F

Rousk J, Bååth E, Brookes PC, Lauber CL, Lozupone C, Caporaso JG, Knight R, and Fierer N. 2010. Soil bacterial and fungal communities across a pH gradient in an arable soil. The Isme Journal 4:1340. 10.1038/ismej.2010.58

She W, Bai Y, Zhang Y, Qin S, Feng W, Sun Y, Zheng J, and Wu B. 2018. Resource availability drives responses of soil microbial communities to short-term precipitation and nitrogen addition in a desert shrubland. Frontiers in Microbiology 9. 10.3389/fmicb.2018.00186

Stevens CJ. 2019. Nitrogen in the environment. Science 363:578-580. 10.1126/science.aav8215 \%J Science

Peer) reviewing PDF | (2019:04:36405:1:0:NEW 1 Aug 2019) 
618 Tan H, Barret M, Mooij MJ, Rice O, Morrissey JP, Dobson A, Griffiths B, O'Gara FJB, and Soils

619

620

621

622

623

624

625

626

627

628

629

630

631

632

633

634

635

636

637

638

639

640

641

642

643

644

645

646

647

648

649

650

651

652

653

654

655

656

657

658

Fo. 2013. Long-term phosphorus fertilisation increased the diversity of the total bacterial community and the phoD phosphorus mineraliser group in pasture soils. 49:661-672. 10.1007/s00374-012-0755-5

Teng Z, Cui J, Wang J, Fu X, and Xu X. 2018. Effect of exogenous nitrogen and phosphorus inputs on the microbe-soil interaction in the secondary Castanopsis sclerophylla forest in east China. iForest - Biogeosciences and Forestry 11:794-801. 10.3832/ifor2673-011

Tian D, and Niu S. 2015. A global analysis of soil acidification caused by nitrogen addition. Environmental Research Letters 10:024019.

Tian J, He N, Hale L, Niu S, Yu G, Liu Y, Blagodatskaya E, Kuzyakov Y, Gao Q, and Zhou J. 2018. Soil organic matter availability and climate drive latitudinal patterns in bacterial diversity from tropical to cold temperate forests. Functional Ecology 32:61-70. 10.1111/1365-2435.12952

Treseder KK. 2008. Nitrogen additions and microbial biomass: a meta-analysis of ecosystem studies. Ecology Letters 11:1111-1120. 10.1111/j.1461-0248.2008.01230.x

Turlapati SA, Minocha R, Bhiravarasa PS, Tisa LS, Thomas WK, and Minocha SC. 2013. Chronic $\mathrm{N}$-amended soils exhibit an altered bacterial community structure in Harvard Forest, MA, USA. FEMS Microbiology Ecology 83:478-493. 10.1111/1574-6941.12009 \%J FEMS Microbiology Ecology

Van Den Berg LJL, Dorland E, Vergeer P, Hart MAC, Bobbink R, and Roelofs JGM. 2005. Decline of acid-sensitive plant species in heathland can be attributed to ammonium toxicity in combination with low pH. New Phytologist 166:551-564. 10.1111/j.14698137.2005.01338.x

Wang Q, Wang C, Yu W, Turak A, Chen D, Huang Y, Ao J, Jiang Y, and Huang Z. 2018. Effects of nitrogen and phosphorus inputs on soil bacterial abundance, diversity, and community composition in Chinese fir plantations. Frontiers in Microbiology 9. 10.3389/fmicb.2018.01543

Wang R, Balkanski Y, Boucher O, Ciais P, Peñuelas J, and Tao S. 2014. Significant contribution of combustion-related emissions to the atmospheric phosphorus budget. Nature Geoscience 8:48. 10.1038/ngeo2324

https://www.nature.com/articles/ngeo2324\#supplementary-information

Weber C, Vilgalys R, and Kuske C. 2013. Changes in fungal community composition in response to elevated atmospheric $\mathrm{CO}_{2}$ and nitrogen fertilization varies with soil Horizon. Frontiers in Microbiology 4. 10.3389/fmicb.2013.00078

Wei H, Peng C, Yang B, Song H, Li Q, Jiang L, Wei G, Wang K, Wang H, Liu S, Liu X, Chen D, Li $Y$, and Wang M. 2018. Contrasting soil bacterial community, diversity, and function in two forests in China. Frontiers in Microbiology 9. 10.3389/fmicb.2018.01693

Xu G, and Liang C. 1965. Division and transormation of secondary forest in Jigongshan Forest Farm. Practical Forestry Technology:8-10 In Chinese. 10.13456/j.cnki.lykt.1965.06.005

Yan J, Zhang W, Wang K, Qin F, Wang W, Dai H, and Li P. 2014. Responses of $\mathrm{CO}_{2}, \mathrm{~N}_{2} \mathrm{O}$ and $\mathrm{CH}_{4}$ fluxes between atmosphere and forest soil to changes in multiple environmental

Peer reviewing PDF | (2019:04:36405:1:0:NEW 1 Aug 2019) 
659

660

661

662

663

664

665

666

667

668

669

670

671

672

673

674

675

676

677

678 conditions. Global Change Biology 20:300-312. 10.1111/gcb.12327

Yao F, Yang S, Wang Z, Wang X, Ye J, Wang X, DeBruyn JM, Feng X, Jiang Y, and Li H. 2017. Microbial taxa distribution is associated with ecological trophic cascades along an elevation gradient. 8. 10.3389/fmicb.2017.02071

Yu L, Wang Y, Zhang X, Dörsch P, and Mulder J. 2017. Phosphorus addition mitigates $\mathrm{N}_{2} \mathrm{O}$ and $\mathrm{CH}_{4}$ emissions in N-saturated subtropical forest, SW China. Biogeosciences 14:30973109. 10.5194/bg-14-3097-2017

Zeng J, Liu X, Song L, Lin X, Zhang H, Shen C, and Chu H. 2016. Nitrogen fertilization directly affects soil bacterial diversity and indirectly affects bacterial community composition. Soil Biology and Biochemistry 92:41-49. https://doi.org/10.1016/j.soilbio.2015.09.018

Zhou Z, Wang C, Zheng M, Jiang L, and Luo Y. 2017. Patterns and mechanisms of responses by soil microbial communities to nitrogen addition. Soil Biology and Biochemistry 115:433441. https://doi.org/10.1016/j.soilbio.2017.09.015

Zhu J, He N, Wang Q, Yuan G, Wen D, Yu G, and Jia Y. 2015. The composition, spatial patterns, and influencing factors of atmospheric wet nitrogen deposition in Chinese terrestrial ecosystems. Science of the Total Environment 511:777-785. http://dx.doi.org/10.1016/j.scitotenv.2014.12.038 


\section{Table $\mathbf{1}$ (on next page)}

Pearson correlations between bacterial and fungal richness and diversity and plant and soil characteristics. 
1 Table 1 Pearson correlations between bacterial and fungal richness and diversity and plant and 2 soil characteristics. $* 0.01<P \leq 0.05 ; * * 0.001<P \leq 0.01$

3

4

6 SOC:

\begin{tabular}{llllll}
\hline \multirow{2}{*}{$r$} & \multicolumn{2}{c}{ Bacteria } & & \multicolumn{2}{c}{ Fungi } \\
\cline { 2 - 3 } \cline { 5 - 6 } Fine root biomass & $0.59^{*}$ & $0.56^{*}$ & & $0.51^{*}$ & 0.32 \\
pH & $0.80^{* *}$ & $0.71^{* *}$ & & $0.57^{*}$ & 0.41 \\
SOC & $-0.52^{*}$ & -0.40 & & -0.29 & -0.47 \\
TN & -0.47 & -0.35 & & -0.16 & -0.33 \\
C:N ratio & -0.40 & -0.35 & & -0.42 & -0.47 \\
DOC & $-0.75^{* *}$ & $-0.72^{* *}$ & & -0.32 & -0.20 \\
$\mathrm{NH}_{4}^{+}$ & -0.48 & -0.34 & & -0.23 & -0.17 \\
$\mathrm{NO}_{3}{ }^{-}$ & -0.40 & -0.31 & & -0.15 & -0.02 \\
$\mathrm{AP}$ & 0.07 & 0.24 & & -0.34 & -0.42 \\
$\mathrm{MBC}$ & $-0.64^{* *}$ & -0.49 & & $-0.54^{*}$ & -0.48 \\
$\mathrm{MBN}$ & -0.41 & -0.27 & & -0.40 & -0.42 \\
$\mathrm{Al} 3^{3+}$ & $-0.54^{*}$ & $-0.58^{*}$ & & $-0.62^{*}$ & -0.33 \\
$\mathrm{Ca}^{2+}$ & $0.58^{*}$ & 0.54 & & 0.40 & 0.33 \\
$\mathrm{Mg}^{2+}$ & 0.24 & 0.09 & & 0.22 & 0.13 \\
$\mathrm{Na}^{+}$ & -0.06 & -0.07 & -0.33 & -0.17 \\
\hline
\end{tabular}

7 organic carbon; TN: total nitrogen content; DOC: dissolved organic carbon; AP: available 8 phosphorus; MBC: microbial biomass carbon; MBN: microbial biomass nitrogen.

9

10 
Table 2 (on next page)

Partial mantel test of soil bacterial and fungal community structure with environmental characteristics. 
1 Table 2 Partial mantel test of soil bacterial and fungal community structure with environmental 2 characteristics. The correlation and significance were determined between bacterial and fungal 3 community structure (Bray-Curtis distance) and environmental variables (Euclidean distance) 4 based on 999 permutations.

5

\begin{tabular}{lccccc}
\hline & \multicolumn{2}{c}{ Bacteria } & & \multicolumn{2}{c}{ Fungi } \\
\cline { 2 - 3 } \cline { 5 - 6 } & $r$ & $P$ & & $r$ & $P$ \\
\hline Fine root biomass & $\mathbf{0 . 3 6}$ & $\mathbf{0 . 0 0 5}$ & & 0.10 & 0.18 \\
pH & $\mathbf{0 . 5 7}$ & $\mathbf{0 . 0 0 1}$ & & $\mathbf{0 . 4 0}$ & $\mathbf{0 . 0 0 1}$ \\
SOC & 0.16 & 0.10 & & 0.19 & 0.07 \\
TN & $\mathbf{0 . 2 1}$ & $\mathbf{0 . 0 4}$ & & 0.12 & 0.14 \\
C:N ratio & $\mathbf{0 . 2 2}$ & $\mathbf{0 . 0 4}$ & & $\mathbf{0 . 2 5}$ & $\mathbf{0 . 0 2}$ \\
DOC & $\mathbf{0 . 2 7}$ & $\mathbf{0 . 0 2}$ & & $\mathbf{0 . 2 6}$ & $\mathbf{0 . 0 1}$ \\
$\mathrm{NH}_{4}^{+}$ & 0.08 & 0.21 & & -0.009 & 0.49 \\
$\mathrm{NO}_{3}{ }^{-}$ & 0.07 & 0.26 & & 0.02 & 0.45 \\
$\mathrm{AP}^{-}$ & -0.14 & 0.95 & & -0.13 & 0.92 \\
$\mathrm{MBC}^{\mathrm{MBN}}$ & $\mathbf{0 . 2 4}$ & $\mathbf{0 . 0 3}$ & & $\mathbf{0 . 3 6}$ & $\mathbf{0 . 0 0 4}$ \\
$\mathrm{Al}^{3+}$ & 0.10 & 0.15 & & 0.17 & 0.06 \\
$\mathrm{Ca}^{2+}$ & $\mathbf{0 . 4 0}$ & $\mathbf{0 . 0 0 2}$ & & $\mathbf{0 . 2 1}$ & $\mathbf{0 . 0 3}$ \\
$\mathrm{Mg}^{2+}$ & 0.12 & 0.18 & & -0.06 & 0.66 \\
$\mathrm{Na}^{+}$ & 0.06 & 0.28 & & $\mathbf{0 . 2 7}$ & $\mathbf{0 . 0 2}$ \\
\hline $\mathrm{SOC}^{+}$ & -0.15 & 0.91 & & -0.03 & 0.62 \\
\hline
\end{tabular}

6 SOC: soil organic carbon; TN: total nitrogen content; DOC: dissolved organic carbon; AP: available 7 phosphorus; MBC: microbial biomass carbon; MBN: microbial biomass nitrogen. 
Figure 1

Relative abundance of the dominant bacterial (a) and fungal (b) groups at phylum level under different treatments. 
(a)

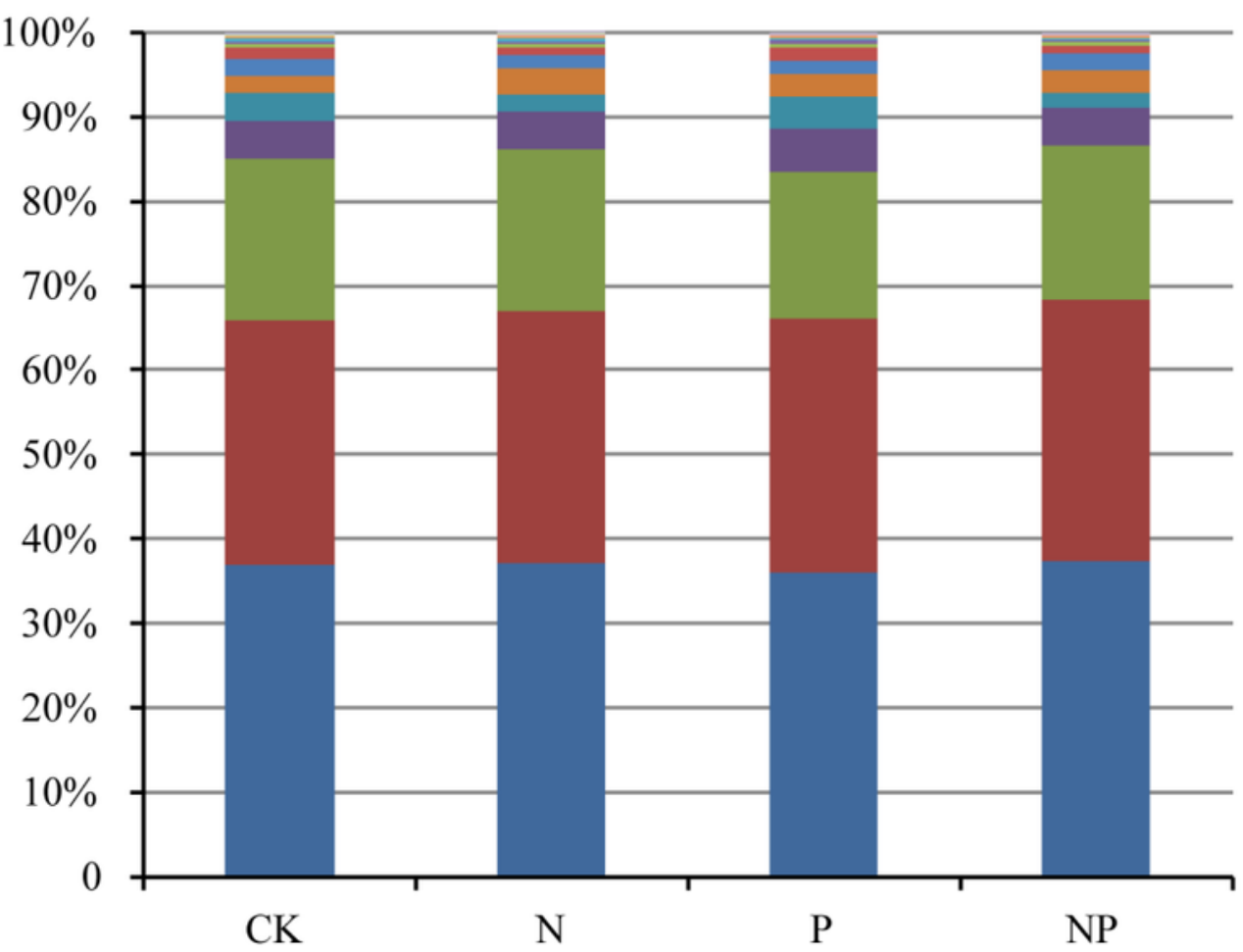

(b)

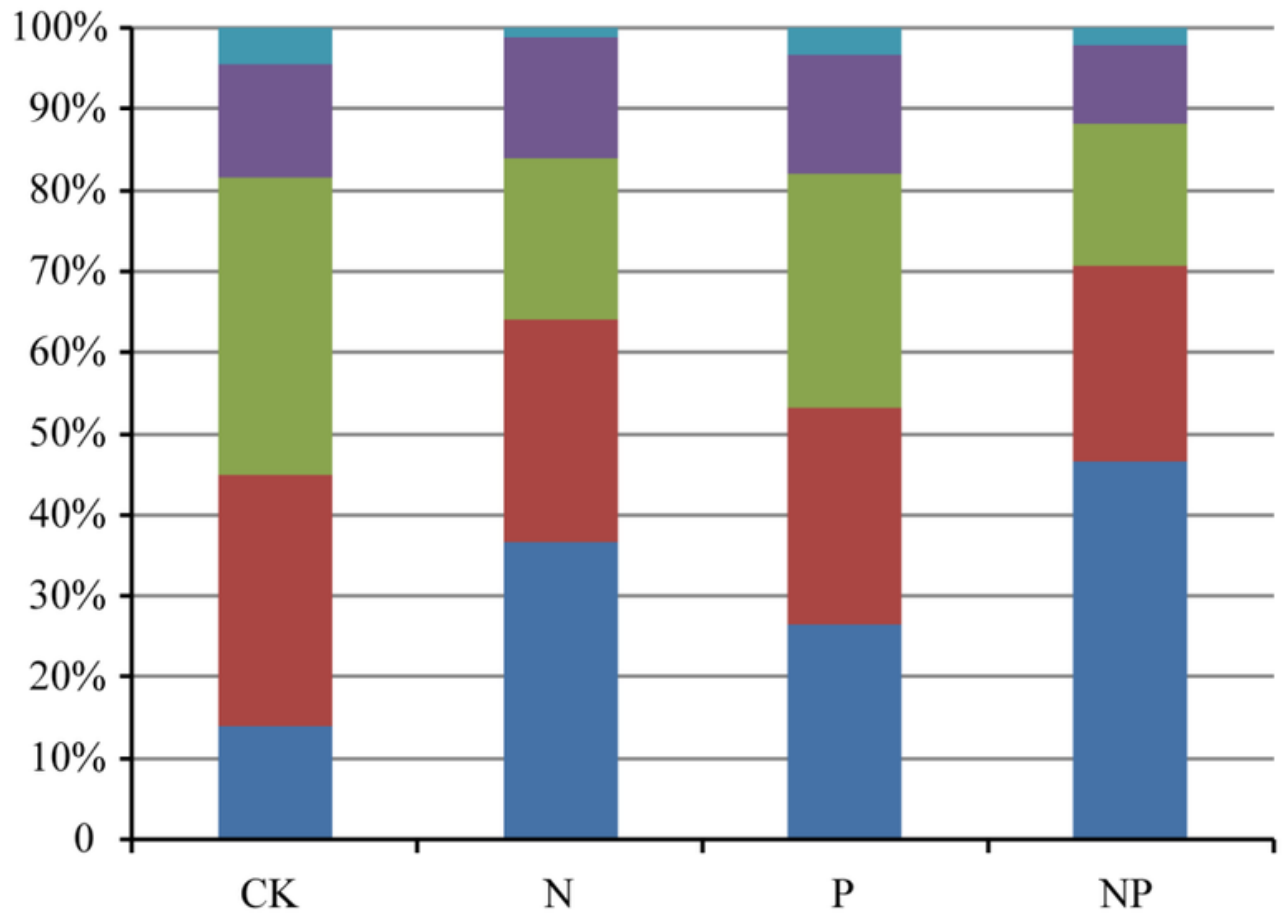

In others

Omnitrophica

- Saccharibacteria

- Dependentiae

- Cyanobacteria

- Elusimicrobia

- Armatimonadetes

- Verrucomicrobia

nemmatimonadetes

- Bacteroidetes

- Firmicutes

- Chloroflexi

- Planctomycetes

- Actinobacteria

- Acidobacteria

- Proteobacteria

घothers

- Rozellomycota

- Zygomycota

- Basidiomycota

- Ascomycota

- unclassified 
Figure 2

Responses ratio analysis of changes in the relative abundance of dominant bacterial phyla (a) and fungal phyla/genera (b) in response to N, P and NP treatment compared to the control treatment, at the $95 \%$ confidence interval.

Red points indicate significant changes compared with the control treatment.

(a)

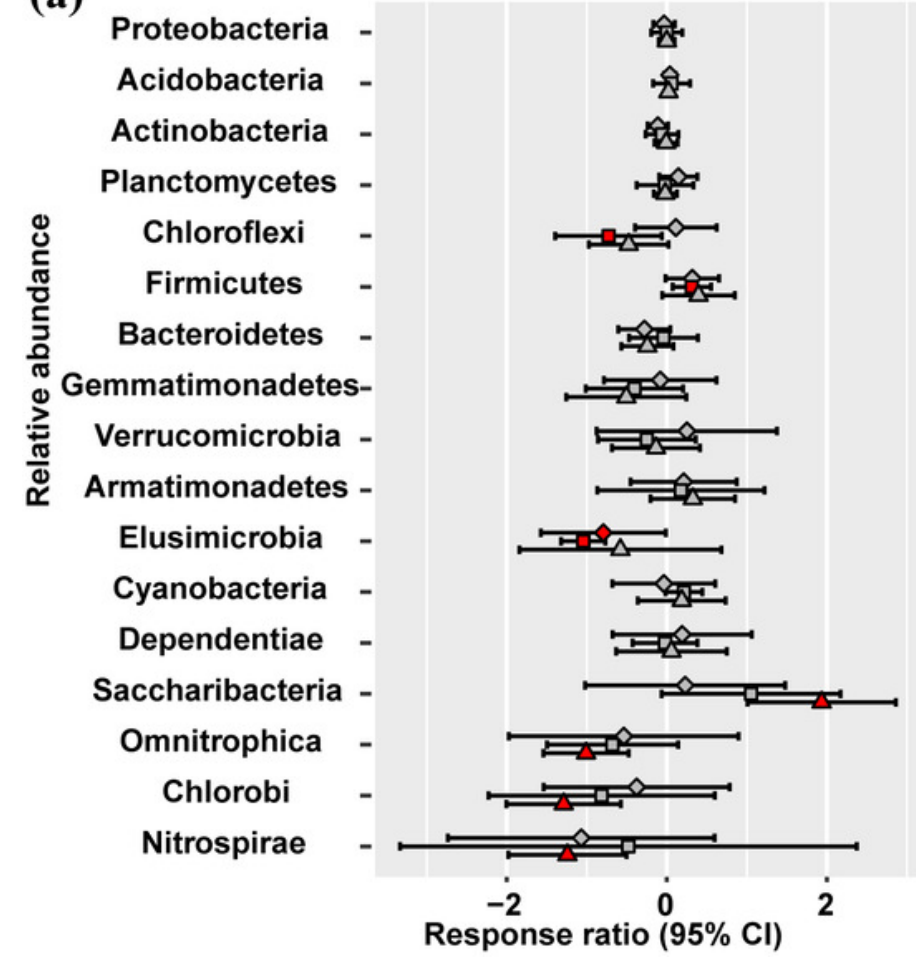

(b)

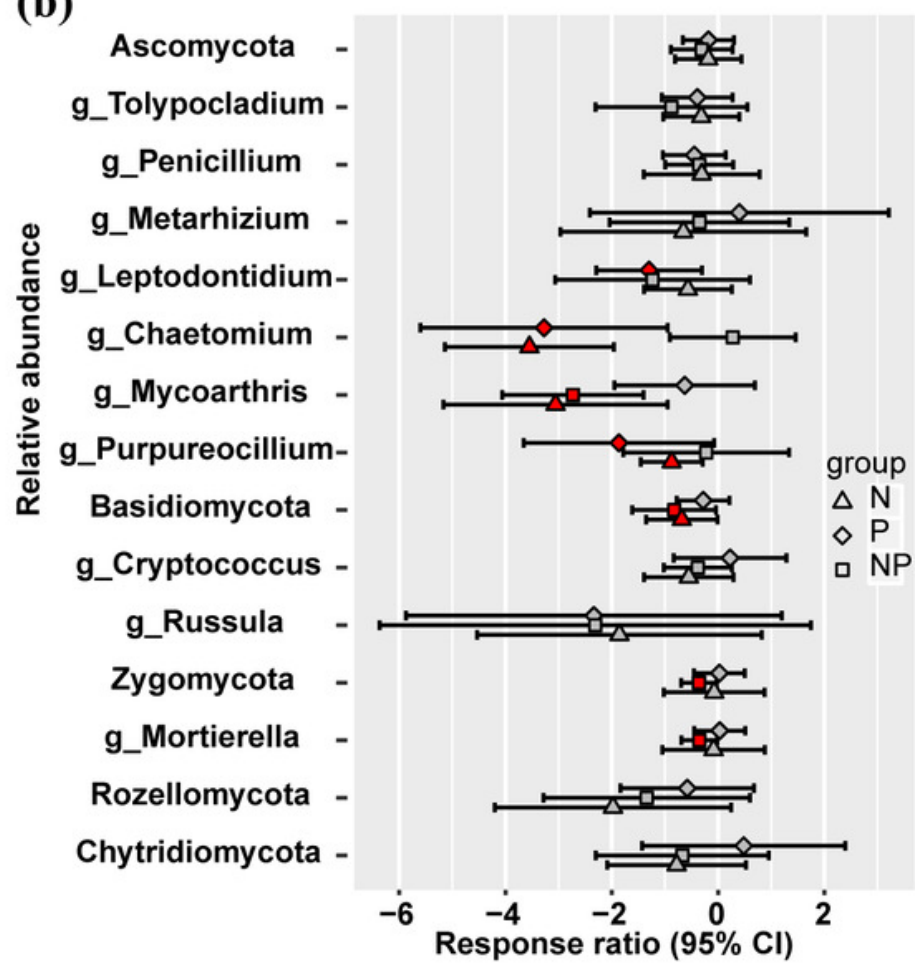


Figure 3

Bacterial and fungal phylotype richness $(\mathrm{a}-\mathrm{b})$ and Shannon diversity index $(\mathrm{c}-\mathrm{d})$ under different treatments.

The error bars represent the SE of the mean $(n=4)$.

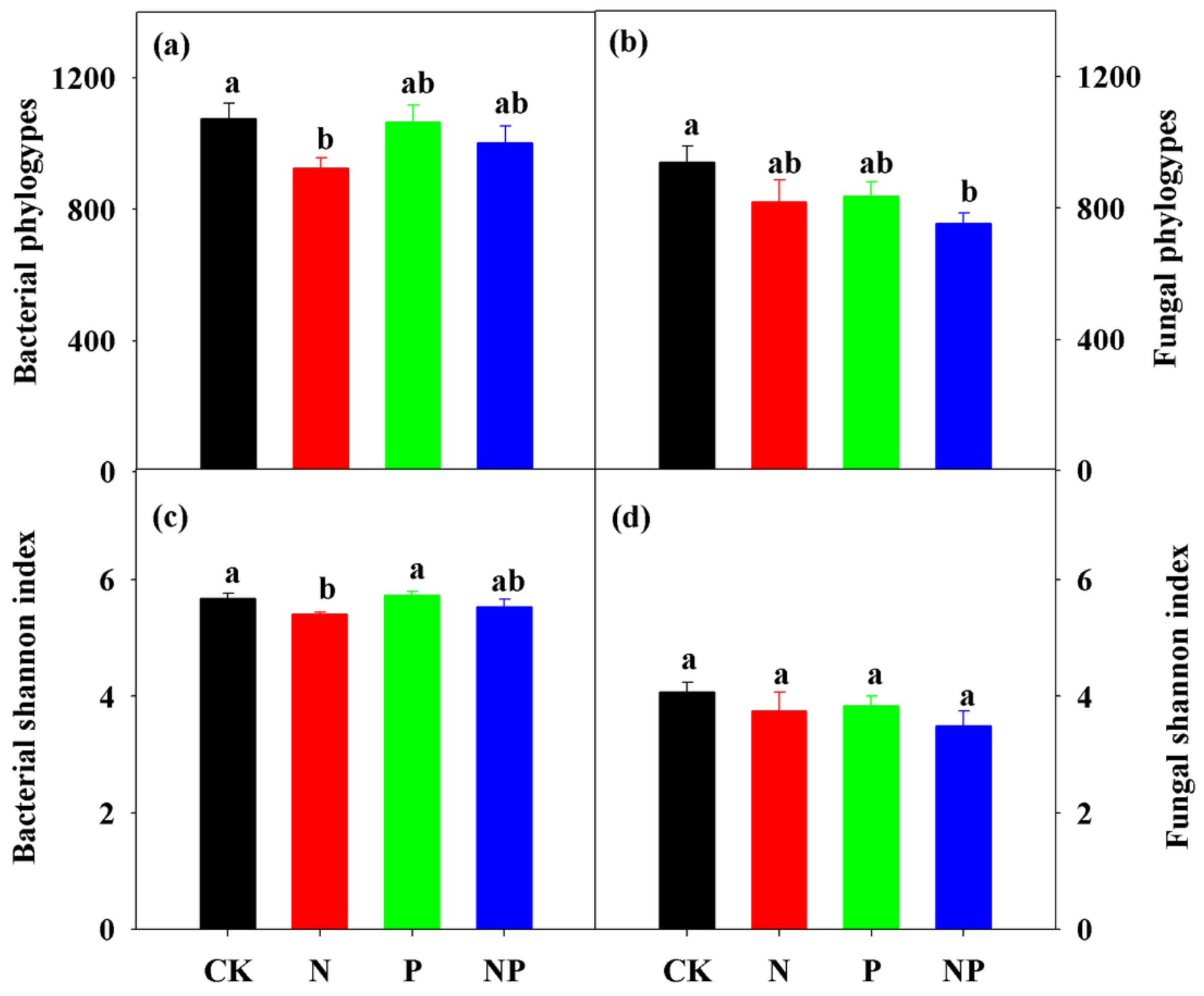


Figure 4

Non-metric multidimensional scaling (NMDS) ordination of the soil bacterial (a) and fungal (b) community structure under different treatments.

The Bray-Curtis distance matrix based on the abundance of OTUs was used to determine the compositional variation. 
(a)

stress :0.081

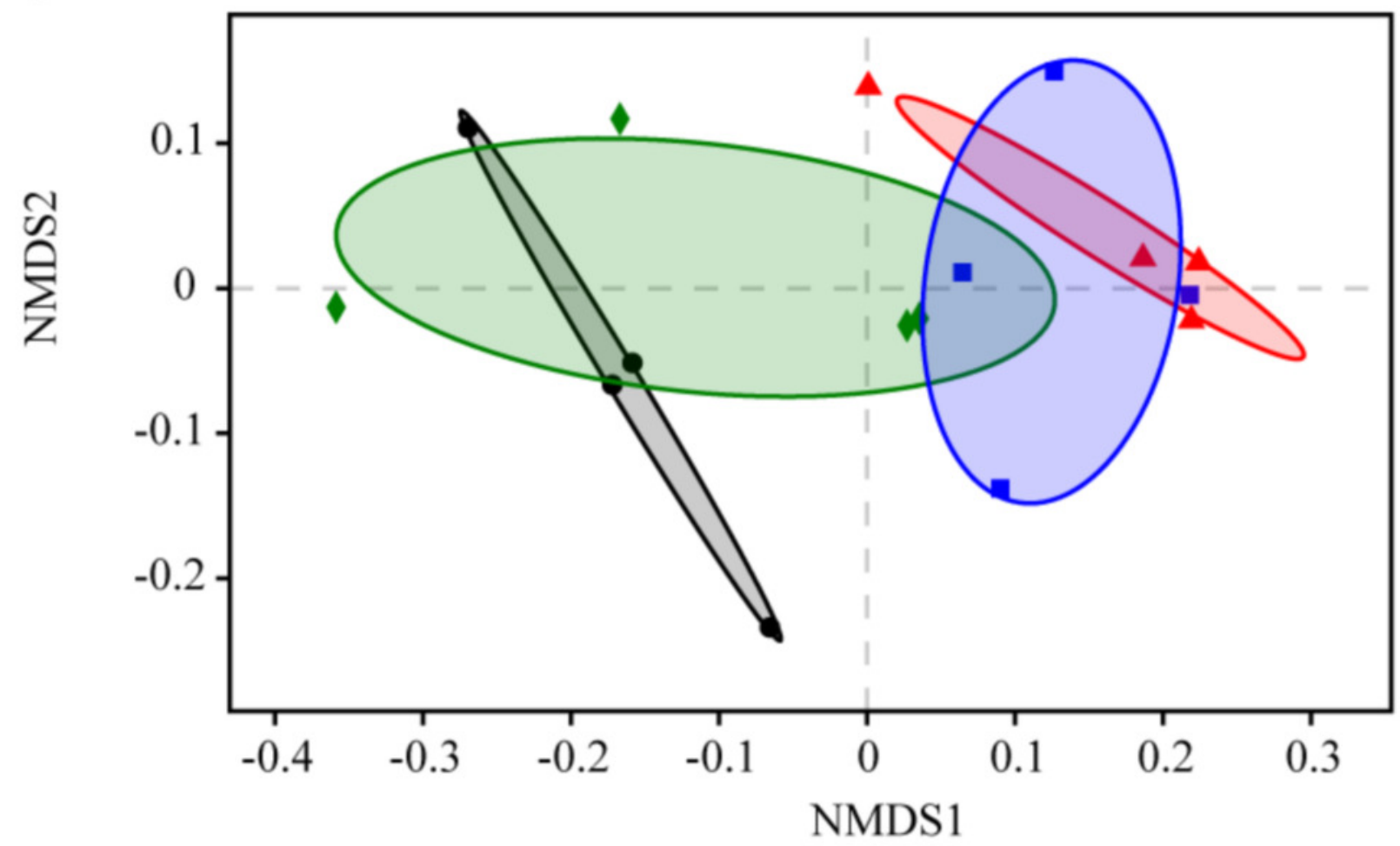

- $\mathrm{CK}$

$\Delta \mathrm{N}$

$\checkmark \mathrm{P}$

- NP

(b)

stress :0.096

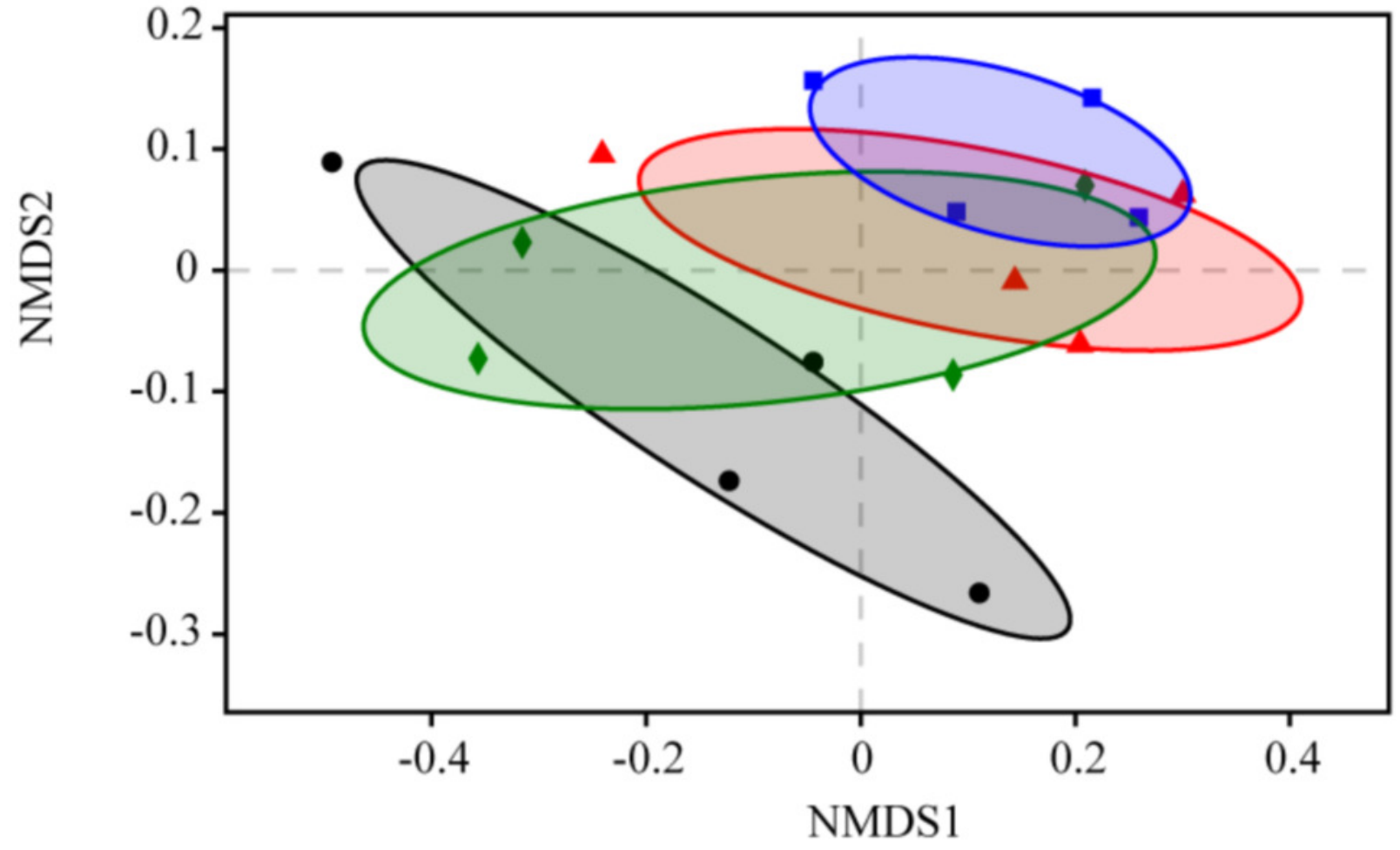




\section{Figure 5}

Structural equation model (SEM) analysis of the effects of $\mathrm{N}$ and $\mathrm{P}$ enrichment on soil bacterial (a) and fungal (b) community structure.

Results of model fitting: (a) $\chi^{2}=19.38, \mathrm{df}=13, P=0.11$, RMSEA $=0.18$, AIC $=65.38$; (b) $\chi^{2}$ $=18.39, \mathrm{df}=13, P=0.14, \mathrm{RMSEA}=0.17, \mathrm{AIC}=64.39$. Black and blue arrows represent significant positive and negative pathways, respectively, and dashed arrows indicate nonsignificant pathways. Numbers at the arrows are standardized path coefficients and arrow width is proportional to the strength of the relationship. $R^{2}$ values on top of response variables indicate the proportion of variation explained by relationships with other variables. Prior to SEM analysis, soil $\mathrm{N}$ availability $\left(\mathrm{NH}_{4}{ }^{+}\right.$and $\mathrm{NO}_{3}^{-}{ }^{-}$), soil acid cations $\left(\mathrm{H}^{+}\right.$and $\left.\mathrm{Al}^{3+}\right)$, soil nutrients (SOC, TN, DOC, MBC and MBN), bacterial and fungal community composition (OTUs) were subject to principal component analysis (PCA) procedure to reduce the number of variables. 
(a)

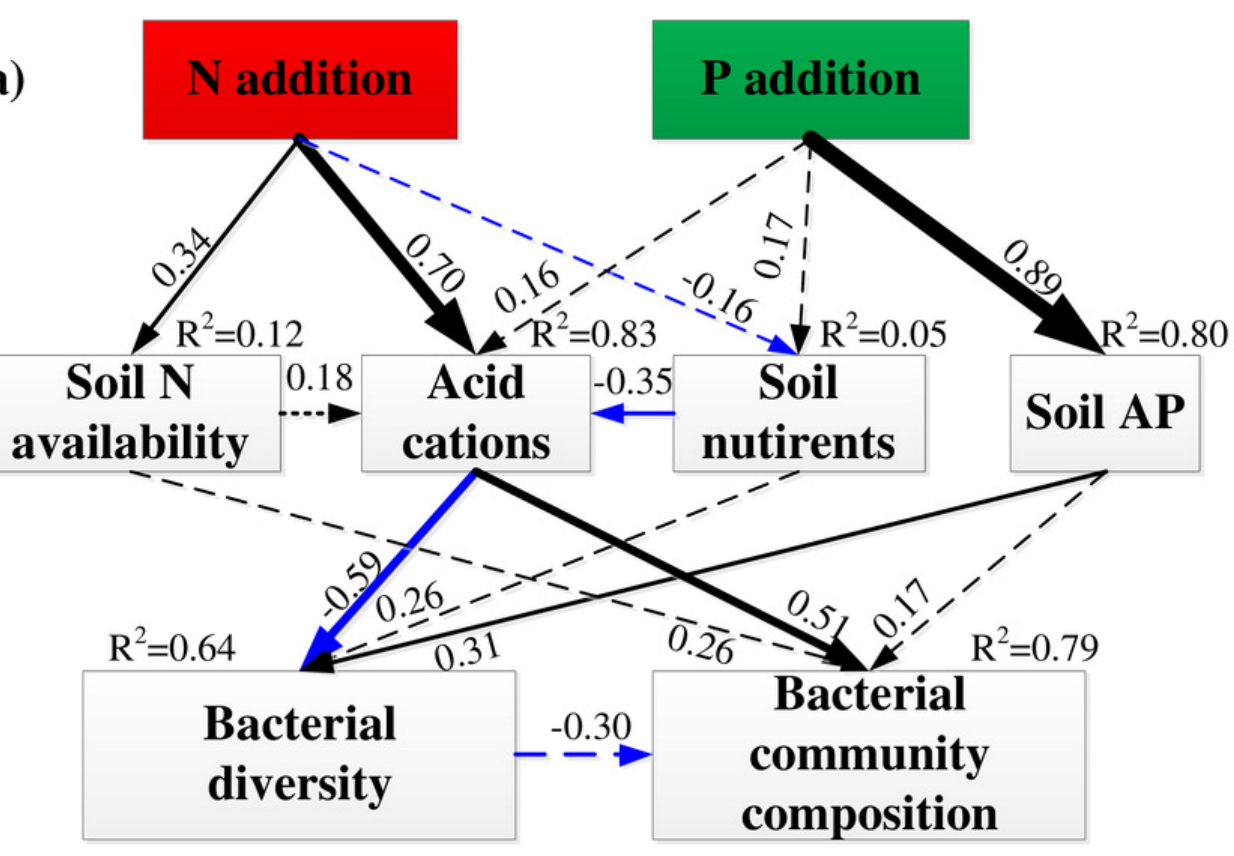

(b)
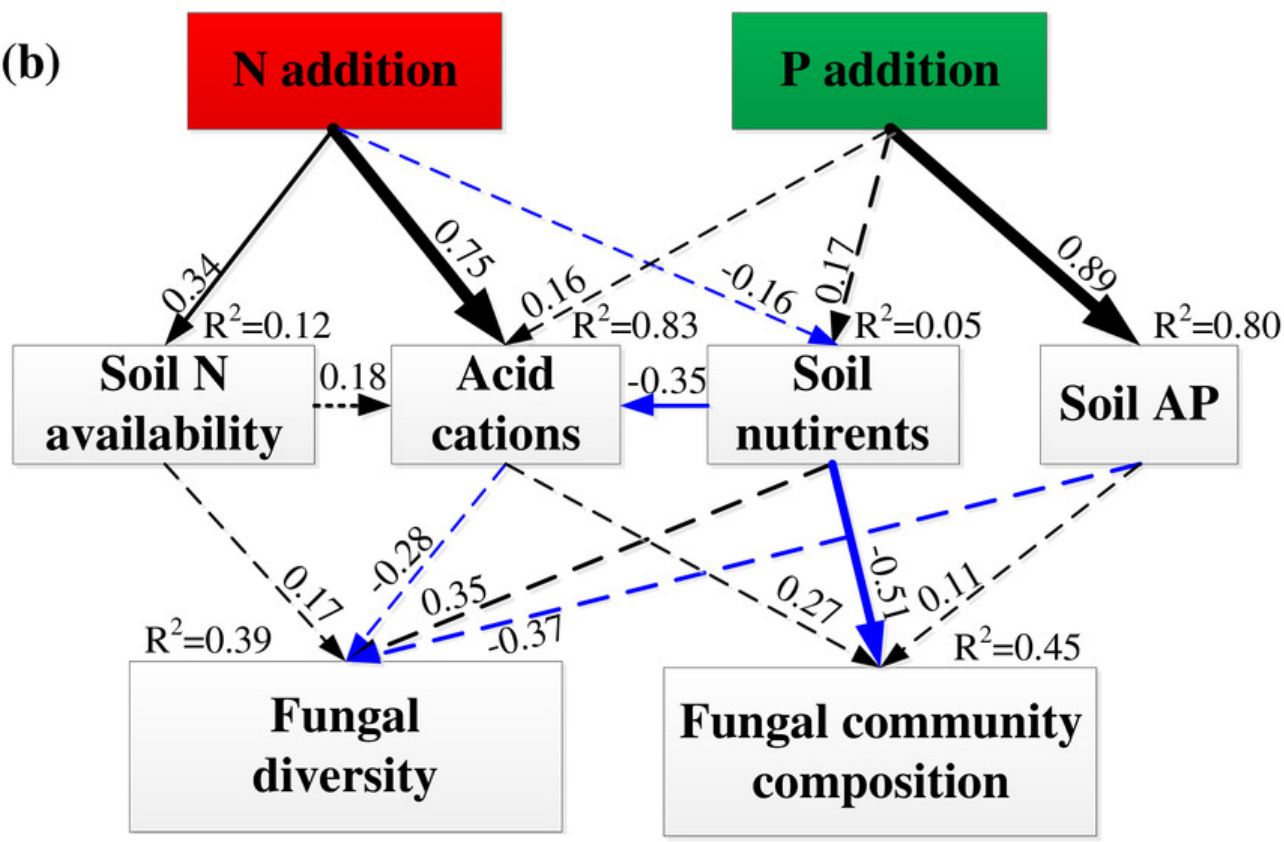
Figure 6

SEM derived standardized total effects of $\mathrm{N}$ and $\mathrm{P}$ additions, and variables including $\mathrm{N}$ availability, acid cations, soil nutrients, and soil available $\mathrm{P}$ on bacterial diversity and community composition (a-b) and fungal diversity (c-d). 


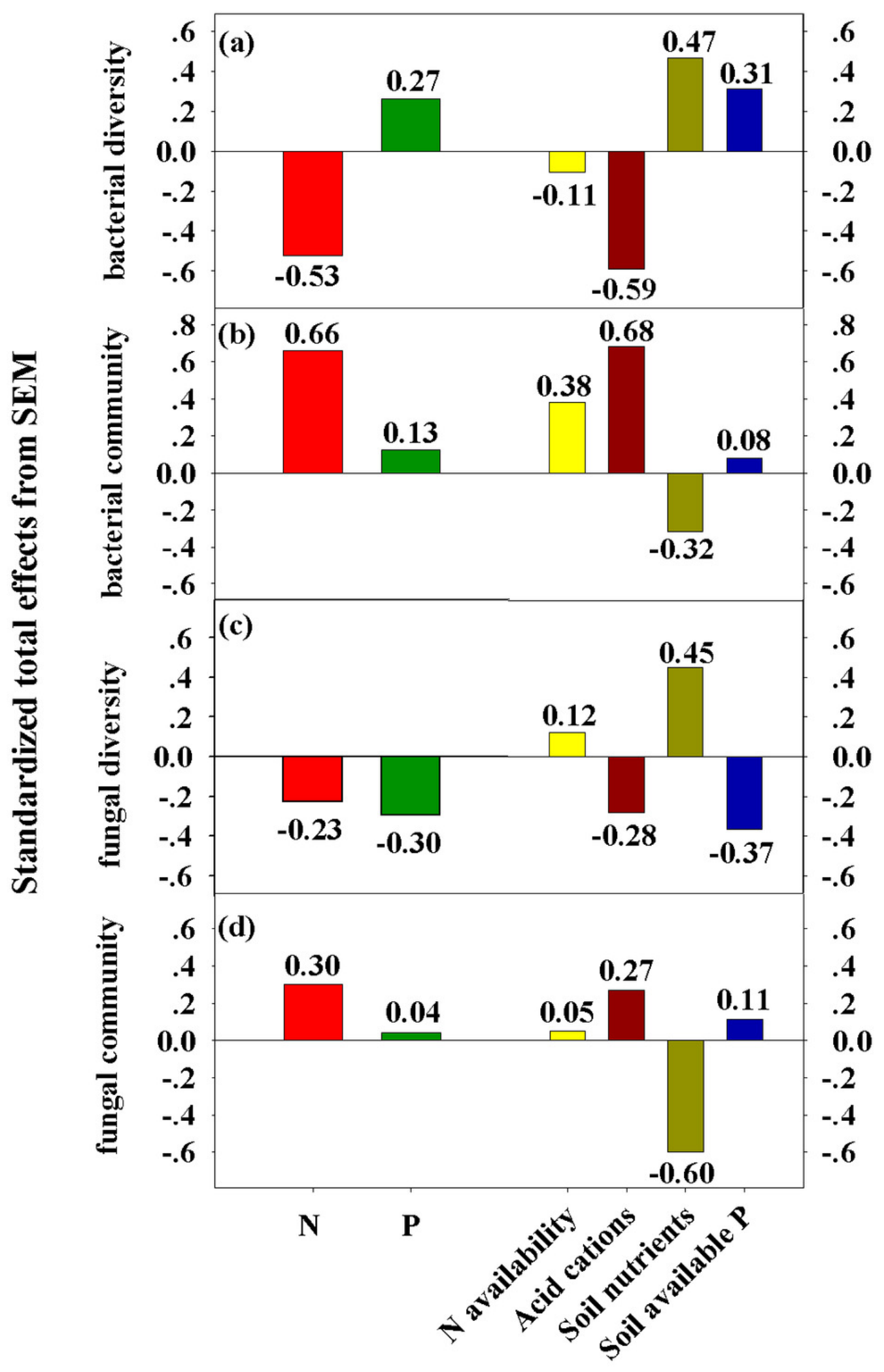

